\title{
Short Selling Restrictions in the EU and the US: A Comparative
}

\author{
Analysis
}

Elizabeth Howell $^{*}$

\section{A. Introduction}

Short selling is a sensitive subject. Setting aside moral concerns about selling something one does not own, short sellers provide convenient targets of criticism as they are, in a sense, seen as betting against the team: they allow investors to profit when the share price falls. ${ }^{1}$ During the 2008 global financial crisis, the price collapse of listed financial securities following the demise of Lehman Brothers brought the issue of short selling onto the centre stage, and regulators around the world imposed temporary short selling bans in an effort to halt the downward spiral in prices. Within the EU, short selling then returned to the spotlight during the subsequent sovereign debt crisis. In particular, as the Greek government showed signs of financial collapse, short sales and credit default swaps ('CDSs') on Greek sovereign debt increased, and certain Member States blamed short sellers for aggravating Greece's financial woes. More recently, as China's stock market experienced dramatic declines during 2015 and early 2016, the Chinese regulators pointed the finger of blame at 'malicious' short

\footnotetext{
${ }^{*}$ Faculty of Law, University of Cambridge. I am grateful to an anonymous referee for their very helpful comments. I have also benefitted from discussing many of the issues considered in this article with Professors John Armour, Pierre-Henri Conac, Luca Enriques, and Jennifer Payne. All errors remain my responsibility.

${ }^{1}$ Jonathan Macey, Mark Mitchell and Jeffry Netter, 'Restrictions on Short Sales: An Analysis of the Uptick Rule and Its Role in View of the October 1987 Stock Market Crash' (1988) 74 Cornell L Rev 799,800 . Short selling can broadly be defined as the sale of an asset (often a security) not owned by the seller in the hope that an identical asset can be bought back later for a lower price, see further section B below.
} 
sellers (amongst others); imposed a variety of short selling restrictions; and instigated a number of market manipulation probes. Likewise, the Greek regulators imposed a further set of temporary short selling bans during 2015 when Greece again teetered on the brink of collapse.

Following the global financial crisis, short selling regulation did not form a key priority on the international G20 reform agenda. ${ }^{2}$ Nevertheless in the US, (a jurisdiction that had regulated short selling in one form or another since the 1930s), the Securities and Exchange Commission (the 'SEC') subsequently implemented a number of new short selling restrictions with respect to equity securities, including reintroducing a type of short sale price test. In the EU (where many jurisdictions had historically never regulated the practice), the Short Selling Regulation (the 'Regulation') was implemented in 2012, largely as a consequence of the sovereign debt crisis. Indeed, the influence of the debt crisis is evident in the Regulation's provisions that not only covers the short selling of equity securities, but also restricts short selling in the sovereign debt markets.

The Regulation also confers a wide set of supervisory powers on the European Securities and Markets Authority ('ESMA'). ${ }^{3}$ In contrast to the powers granted to ESMA's predecessor, the Committee of European Securities Regulators ('CESR'), ESMA has far-reaching operational powers under the Regulation, including facilitation and coordination responsibilities with respect to proposed emergency

\footnotetext{
${ }^{2}$ Niamh Moloney, EU Securities and Financial Markets Regulation (3rd edn, Oxford University Press, 2014) 542 .

${ }^{3}$ The establishment of ESMA, and other related institutional changes, stemmed from the de Larosière report: Jacques de Larosière, 'The High Level Group on Financial Supervision in the EU' (Brussels, 25 February 2009).
} 
measures imposed by national competent authorities ('NCAs'). In addition, ESMA's powers also enable it to directly intervene with respect to short selling in exceptional circumstances. ESMA's new powers considerably extend its authority beyond that granted to CESR, and illustrate a major step forward with respect to EU intervention in markets. ${ }^{4}$

Today, both the US and EU short selling regimes are now well established and despite the turbulence in financial markets observed at the start of 2016, there are some signs of improvement with respect to financial stability in advanced economies. ${ }^{5}$ Nevertheless, the IMF also recently highlighted a 'triad of policy challenges' clouding the global financial outlook. ${ }^{6}$ Such concerns included risks with respect to emerging market vulnerabilities (especially in relation to China); legacy issues from the crises (particularly when the possibility of a Greek euro exit flared up again in 2015); plus concerns as to worsening market liquidity. Notably, the IMF also observed that the EU restrictions on short selling, including on sovereign CDSs, had negatively impeded market liquidity, ${ }^{7}$ and it cautiously suggested that the sovereign CDS restrictions should be revoked. ${ }^{8}$

\footnotetext{
${ }^{4}$ See further e.g. Niamh Moloney, 'The European Securities and Markets Authority and Institutional Design for the EU Financial Market - a Tale of Two Competences: Part (2) Rules in Action' (2011) 12 European Business Organization Law Review 177; Carmine Di Noia and Matteo Gargantini, 'Unleashing the European Securities and Markets Authority: Governance and Accountability after the ECJ Decision on the Short Selling Regulation (Case C-270/12)' (2014) 15 EBOR 1.

${ }^{5}$ See e.g. Katie Allen, 'IMF Director Urges Governments to 'Pick up the Growth Baton', Guardian (5 April 2016). Indeed, in the EU for instance, the European Commission's recent Capital Market Union initiative reflects more of a return to 'barrier dismantling' rather than seeking to use integration as a means of managing risk and enforcing financial stability, see European Commission, 'Action Plan on Building a Capital Markets Union’ (COM(2015) 468 final).

${ }^{6}$ IMF, Global Financial Stability Report (October 2015), Preface. See also IMF, Global Financial Stability Report (April 2016) where the IMF observed that risks to global financial stability had increased since the October 2015 report amid volatility in the global stock markets; weaker confidence; and geopolitical tensions.

${ }^{7}$ IMF, Global Financial Stability Report. The IMF defines market liquidity as the ability to execute sizeable securities transactions easily, at a low cost, and with a limited price impact. See IMF, Global Financial Stability Report (April 2015). See also Financial Stability Board, Implementation and Effects
} 
With this broader backdrop in mind, the purpose of this article is to analyse the regulatory choices that have been made with respect to short sale restrictions in the EU and the US. ${ }^{9}$ It should be observed at the outset that although regulatory concerns about short selling often focus on the risk that the practice may exacerbate a downward drop in prices, leading to disorderly markets, the economic literature largely supports the market efficiency and liquidity benefits of short selling, and does not generally endorse the view that short selling destabilises prices. ${ }^{10}$ The economic research also generally demonstrates that short selling restrictions hinder valuable short selling activity and mean that markets will be less efficient. ${ }^{11}$ Further, there is also little convincing evidence that short selling constraints in fact support prices and prevent price declines. ${ }^{12}$ Indeed the voluminous empirical literature examining the temporary short selling bans imposed during the financial crisis also evidences that

of the G20 Financial Regulatory Reforms (November 2015) where, amongst key areas identified for on-going attention, analysing the causes and financial stability consequences of any shifts in market liquidity is highlighted.

${ }^{8}$ In line with the findings related to short selling bans in the equity markets, the IMF found that the restrictions could distort markets and reduce liquidity not only in the sovereign CDS market but also in the underlying cash market, see IMF, Global Financial Stability Report (n 6) Chapter 2. See also section $\mathrm{C}$ below.

${ }^{9}$ It is beyond the scope of this article to examine the approach taken to short selling reporting rules. For such a discussion, see e.g. Jennifer Payne, 'The Regulation of Short Selling and Its Reform in Europe' (2012) 13 EBOR 413; Moloney (n 2) 561-564; Elizabeth Howell, 'Short Selling Reporting Rules in the EU and the US: A Greenfield Area' (2015) 12 European Company Law Journal 79.

${ }^{10}$ Edward M. Miller, 'Risk, Uncertainty, and Divergence of Opinion' (1977) 32 J Fin 1151; Douglas W. Diamond and Robert E. Verrecchia, 'Constraints on Short-Selling and Asset Price Adjustment to Private Information' (1987) 18 Journal of Financial Economics 277; Pedro A. C. Saffi and Kari Sigurdsson, 'Price Efficiency and Short Selling' (2011) 24 Rev Fin Stud 821.

${ }^{11}$ Yang Bai, Eric Chang and Jiang Wang, 'Asset Prices under Short-Sales Constraints' (2006) Working Paper <http://web.mit.edu/wangj/www/pap/BCW_061112.pdf> accessed 10 December 2012; Harrison Hong and Jeremy C. Stein, 'Differences of Opinion, Short-Sales Constraints, and Market Crashes' (2003) 16 Rev Fin Stud 487.

\footnotetext{
${ }^{12}$ See Hong and Stein (n 11). For further discussion, see Section C below.
} 
the temporary constraints did not achieve their aim of stabilising prices and may have impeded market quality. ${ }^{13}$

A further justification behind the 2008 temporary short selling bans was the heightened risk of market abuse posed by short sellers during periods of market turbulence. ${ }^{14}$ For instance, short selling can be potentially used abusively to create misleading signals about the real supply or the correct valuation of a security, and it can also be used with scaremongering tactics to push the price of a security down. ${ }^{15}$ The former UK regulator, the FSA, observed that firms engaging in seasoned equity offerings ('SEOs') may be especially vulnerable to short selling's negative effects. For example, on a rights issue, short sellers could try to push down the share price in the market below the rights issue price in order to profit from the strategy, and the FSA suggested that when confidence in firms was more fragile, it would be easier for short sellers to push the price into a downwards spiral. ${ }^{16}$

Although these are serious regulatory concerns, it should first be observed that any abusive shorting behaviour is likely to be already illegal under existing market manipulation legislation, and that regulators have a range of options (including administrative and criminal sanctions) under such regimes that can be used to combat

\footnotetext{
${ }^{13}$ Alessandro Beber and Marco Pagano, 'Short-Selling Bans around the World: Evidence from the 2007-09 Crisis' (2013) 68 J Fin 343; Ekkehart Boehmer, Charles M. Jones and Xiaoyan Zhang, 'Shackling Short Sellers: The 2008 Shorting Ban' (2013) 26 Rev Fin Stud 1363; Arturo Bris, 'Short Selling Activity in Financial Stocks and the SEC July 15th Emergency Order' (2008) <http://vvwvv.arturobris.com/eo/brisreportAug12.pdf> accessed 19 November 2012; Matthew Clifton and Mark Snape, 'The Effect of Short-Selling Restrictions on Liquidity: Evidence from the London Stock Exchange' (2008).

${ }^{14}$ FSA, 'Short Selling Discussion Paper 09/1' (2009) 3.

${ }^{15}$ Ibid 11-12.

${ }^{16}$ Ibid 11-12.
} 
any such behaviour. ${ }^{17}$ Further, when reflecting on the relevant economic literature, (which largely focuses on SEOs), this generally suggests that there is only limited evidence as to manipulative short selling behaviour. ${ }^{18}$ It also broadly suggests that imposing short sale constraints could result in adverse consequences. For instance, a recent paper by Autore and Gehy found that short sale restrictions could impact market efficiency and have unintended consequences on the capital raising process. ${ }^{19}$

In sum, the economic literature largely supports the market efficiency and liquidity benefits of short selling, and generally does not endorse the view that short selling destabilises prices, or is an abusive practice per se. Nonetheless, despite the absence of clear legal or economic grounds justifying regulatory intervention in this area (particularly the imposition of short selling restrictions), short sellers have been subject to a range of short selling restrictions in the US since the 1930s, and in the EU since 2012.

This article adds to the existing literature on short selling regulation through analysing the permanent and temporary short selling constraints now in place on both sides of

\footnotetext{
${ }^{17}$ As discussed further in section C below, the EU market abuse reforms that take effect in July 2016 also adopt a more prescriptive approach to sanctions as well.

${ }^{18}$ See e.g. Assem Safieddine and William J. Wilhelm, 'An Empirical Investigation of Short-Selling Activity Prior to Seasoned Equity Offerings' (1996) 51 J Fin 729; Kenneth A. Kim and Hyun-Han Shin, 'The Puzzling Increase in the Underpricing of Seasoned Equity Offerings' (2004) 39 Financial Review 343; Charles Jones, Adam Reed and Wiliam Waller, 'Revealing Shorts: An Examination of Large Short Position Disclosures’ (AFA 2013 San Diego Working Paper). For an alternative view see e.g. Tyler Henry and Jennifer Koski, 'Short Selling around Seasoned Equity Offerings' (2010) 23 Rev Fin Stud 4389. Note however that the studies do vary in terms of methodological choices, and it is acknowledged that this makes comparisons tricky. Nonetheless the studies broadly show only limited evidence as to manipulative activity; and that imposing restrictions can have adverse consequences.

${ }^{19}$ Don M. Autore and Dominique Gehy, 'Changing the Rules Again: Short Selling in Connection with Public Equity Offers' (2013) 37 Journal of Banking \& Finance 1974. The unintended consequences included greater discounting with respect to overnight offers that are not announced in advance (the requirements will exclude some buyers and result in underwriters setting a lower offer price to ensure distribution). For similar findings that short selling constraints can result in adverse consequences see e.g. Kim and Shin (n 18); Jones, Reed and Waller (n 18).
} 
Atlantic. It demonstrates that, although some functional similarities are evident, divergences also exist, not least in the absence of restrictions on the short selling of sovereign debt in the US. Further, aside from the EU's regulation of the sovereign debt markets, the short selling restrictions in place in the US are in fact more onerous than those in the EU. This article suggests that this outcome may be, in part, explained by the fact that the SEC is an agency that is 'at once independent and beholden'; ${ }^{20}$ it has to go 'cap in hand' to Congress for its funding on an annual basis. ${ }^{21}$ Further, as a regulatory body, the SEC was also considerably weakened by the financial crisis. Consequently, in terms of the future direction of its short selling policy, it may well have been partly seeking to placate its political critics in order to maintain its jurisdiction going forward. ${ }^{22}$ Turning to the EU, although the legislative passage of the Regulation was also a highly politicised affair, some of the more interventionist proposals could ultimately be watered down during the Regulation's lengthy negotiation process. ${ }^{23}$

\section{B. What is Short Selling?}

Short selling can broadly be defined as the sale of an asset (often securities) not owned by the seller in the hope that an identical asset can be bought back later for a lower price. The definition varies but the International Organisation of Securities

\footnotetext{
${ }^{20}$ Erik R. Sirri, 'Regulatory Politics and Short Selling' (2010) 71 University of Pittsburgh Law Review $517,534$.

${ }^{21}$ Indeed, Congress maintains an increasingly tight rein on the SEC's policy, especially via the budgetary process, see Donald Langevoort, 'The SEC as a Lawmaker: Choices About Investor Protection in the Face of Uncertainty' (2006) 84 Washington University Law Review 1591; Donald Langevoort, 'The SEC and the Madoff Scandal: Three Narratives in Search of a Story' (Georgetown Law Faculty Research Paper, September 2009).

${ }^{22}$ Sirri (n 20) 535.

${ }^{23}$ Moloney (n 2) 545-6.
} 
Commissions ('IOSCO') takes the view that whether a particular transaction is a short selling activity depends on the presence of two factors: (i) a sale of stock that (ii) the seller does not own at the point of sale. ${ }^{24}$ Short selling can be divided into two types: (i) conventional or 'covered' short selling where a security is borrowed or adequate arrangements are made to ensure it can be borrowed before the short sale is executed and (ii) 'naked' or 'uncovered' short selling where no prior arrangement has been made to cover the short sale. ${ }^{25}$ With naked short selling the investor sells the securities before borrowing them or ensuring they can be borrowed and this is possible because there is a gap between the agreement to transfer the securities to the buyer at a particular price and the actual payment and transfer.

\section{Sovereign Debt and CDSs}

The EU rules also regulate the short selling of sovereign debt and sovereign CDSs. Broadly, in order to express a negative view on the evolving credit risk of the sovereign issuer, market participants can directly short sell a sovereign bond. However bonds reflect risk other than credit risk (for instance interest rate risk), and it can also be tricky to short sell bonds (especially corporate bonds), as there is no active secondary market for a large part of the bonds outstanding. ${ }^{26}$ An equivalent mechanism involves purchasing a sovereign CDS. This is an over-the-counter ('OTC') product and where an investor purchases a CDS without some kind of exposure to the credit risk associated with the underlying bond (for instance where the

\footnotetext{
${ }^{24}$ IOSCO, 'Regulation of Short Selling, Final Report' (June 2009), Appendix III.

${ }^{25}$ Ibid 23.

${ }^{26}$ European Commission, Impact Assessment Accompanying Document to the Proposal for a Regulation of the European Parliament and of the Council on Short Selling and Certain Aspects of Credit Default Swaps SEC(2010) 1055, 13.
} 
investor does not hold the debt instrument) this is described as having an uncovered or naked CDS. Naked CDSs provide a relatively simple mechanism for expressing a negative view on credit risk and such purchases do not involve the same required outlay as purchasing a bond.

\section{Regulatory Concerns about Short Selling}

Three perceived concerns are commonly voiced about short selling: market destabilisation; market abuse; and settlement risk. ${ }^{27}$ First, as discussed in section A, there is a popular perception that in extreme market conditions short selling can trigger an excessive downward spiral in share prices leading to disorderly markets. ${ }^{28}$ Although such concerns are understandable, it is important to first appreciate that short sellers can be viewed as sophisticated investors, akin to analysts, who invest considerable time and resources analysing companies. ${ }^{29}$ Indeed, short sellers take considerable financial risks when engaging in shorting activity. Although they can profit when the share price falls, the price can only ever fall to zero, capping any potential gain. In contrast, if the share price rises (and there is no cap on it rising), a short seller can be caught in what is known as a 'short squeeze' where they can suffer severe, indeed potentially unlimited, financial losses.

\footnotetext{
${ }^{27}$ See e.g. European Commission Proposal for a Regulation on Short Selling and Certain Aspects of Credit Default Swaps COM(2010) 482, 2-3; IOSCO (n 24) Appendix II; FSA, (n 14) Chapter 3.

${ }^{28}$ See e.g. Short Selling Proposal (n 27) 2-3; Impact Assessment (n 26) 24-32; FSA (n 14) Chapter 3; IOSCO (n 24) Appendix II, 21.

${ }^{29}$ Zohar Goshen and Gideon Parchomovsky, 'The Essential Role of Securities Regulation' (2006) 55 Duke LJ 711, 732. Indeed, some studies suggest that short sellers' contribution to market efficiency is greater than that of analysts through providing a counter-balance through arbitrage trading, see Michael S. Drake, Lynn Rees and Edward P. Swanson, 'Should Investors Follow the Prophets or the Bears? Evidence on the Use of Public Information by Analysts and Short Sellers' (2011) 86 Acc Rev 101, 125.
} 
Indeed, this is not merely a theoretical observation. In October 2008, many hedge funds held short positions in Volkswagen's shares on the assumption that the price was going to fall. ${ }^{30}$ Porsche however then disclosed that it had raised its stake in Volkswagen to 42.6 per cent from below 35 per cent, and that it held cash settled options for another 31.5 per cent. This announcement sent Volkswagen's share price skyward. ${ }^{31}$ Hedge funds were faced with a short squeeze, and this was particularly exacerbated by the fact that only six per cent of Volkswagen's shares were trading freely, meaning the pressure on those shares was enormous. Ultimately, the Porsche disclosure resulted in huge losses to numerous hedge funds, and although there was some schadenfraude in the press about 'payback' for the hedge fund 'locusts', 32 market, academic, and media reaction all complained about a lack of transparency with respect to Porsche's actions. ${ }^{33}$

Next, although short sellers seek to push the share price lower, this is precisely their role. Specifically, and as observed in section A, the economic literature extensively demonstrates that short selling helps promote market efficiency. It provides a means by which short sellers who know a security is overvalued can trade on the information promoting more efficient pricing. ${ }^{34}$ Short selling also contributes to more efficient price discovery: unfavourable price information is likely to adjust quicker in the

\footnotetext{
${ }^{30}$ This view was due to the global automotive industry crisis. Porsche had also been increasing its stake in Volkswagen, pushing the price above the level it would make economic sense to buy any further stake in it, see e.g. 'Squeezy Money' The Economist (30 October 2008).

${ }^{31}$ Armin Kammel, 'The Dilemma of Blind Spots in Capital Markets - How to Make Efficient Use of Regulatory Loopholes?' (2009) 10 German LJ 605, 615.

${ }^{32}$ See e.g. Gordon Rayner, 'Porsche and VW Share Row: How Germany Got Revenge on the Hedge Fund 'Locusts'" The Telegraph (29 October 2008).

${ }^{33}$ Kammel (n 31) 618. The losses were not purely financial either; a German billionaire took his own life following the Volkswagen losses.

${ }^{34}$ Miller (n 10).
} 
absence of short selling constraints. ${ }^{35}$ Indeed rather than being a suspect activity, short selling confers a 'positive externality' on the market, by speeding up the reflection of unfavourable information into prices. ${ }^{36}$ Likewise it also increases market efficiency through enhancing liquidity and trading opportunities. It raises the number of potential sellers in the market and this enhances liquidity by increasing trading volumes and reducing transaction costs by decreasing bid-ask spreads. ${ }^{37}$

Consequently, if short selling is prohibited, not all information will be fully reflected in share prices. Further, if short sellers are forced out of the market, only optimistic investors will influence the price and this could create and fuel a speculative market bubble. ${ }^{38}$ Indeed, as highlighted in section A, the voluminous empirical literature on short selling restrictions, particularly the studies examining the temporary short selling bans imposed during the financial crisis, largely demonstrates that bans do not achieve their goal of stabilising share prices or preventing price declines, and that they can also compromise market quality. ${ }^{39}$

For instance an influential study by Boehmer et al. examined the US emergency order that temporarily banned short sales in nearly 1,000 financial stocks in September

\footnotetext{
${ }^{35}$ Diamond and Verrecchia (n 10).

${ }^{36}$ Ronald J. Gilson and Reiner H. Kraakman, 'The Mechanisms of Market Efficiency Twenty Years Later: The Hindsight Bias' (2003) 28 J Corp L 715, 727.

${ }^{37}$ FSA ( $n$ 14) 10. The bid-ask spread can be defined as the difference in price between the highest price the buyer is willing to pay for a security and the lowest price a seller is willing to sell it.

${ }^{38}$ Eli Ofek and Matthew Richardson, 'Dotcom Mania: The Rise and Fall of Internet Stock Prices' (2003) 58 J Fin 1113, 1116.

${ }^{39}$ E.g. Boehmer, Jones and Zhang (n 13); Beber and Pagano (n 13); Clifton and Snape (n 13). With respect to evidence relating to the 2010 temporary German ban on the sovereign CDS market, see e.g. Xiaoling Pu and Jianing Zhang, 'Sovereign CDS Spreads, Volatility, and Liquidity: Evidence from 2010 German Short Sale Ban’ (2012) 47 Financial Review 171.
} 
$2008 .^{40}$ The authors observed a large price increase for banned securities on its announcement followed by gradual decreases in price during the ban. ${ }^{41}$ It was recognised that the price increase around the ban's announcement could have been affected by associated announcement as to the US government's bank rescue package (the 'Troubled Asset Relief Program'). The authors found that all but the smallest securities subject to the ban suffered a serious degradation in market quality and concluded that 'given the evidence, it is not at all clear that the SEC achieved its unstated goal of artificially raising prices on financial stocks, and it is clear that market quality was severely compromised'. ${ }^{42}$

Next, although there are real and serious concerns that exist as to manipulative behaviour, and although short selling can be used abusively, the practice is not abusive per se. Additionally, and as observed in section A, most jurisdictions have comprehensive market abuse regimes in place that should be sufficient to address this concern, if used effectively. Although such rules generally take the form of 'ex post' liability rules, imposing additional 'ex ante' short selling restrictions would restrict legitimate short selling activity and would also have a negative impact on pricing efficiency and liquidity. Further, given that long positions (the more conventional method of purchasing securities with the intention of selling them for a profit) also raise issues of market manipulation, the correct regulatory response should be to target all manipulative behaviour occurring rather than singling out short sales.

\footnotetext{
${ }^{40}$ Boehmer, Jones and Zhang (n 13).

${ }^{41}$ Ibid 1398.

${ }^{42}$ Ibid 1399.
} 
Finally, settlement concerns arise because of the need for settlement periods. Specifically, given the nature of securities, a type of settlement period is necessary as purchasers and sellers are not present in the market to exchange cash and shares. Where short sellers fail to deliver shares that they have sold in time for settlement this can cause settlement disruption, which can impair the orderly functioning of markets. ${ }^{43}$ Despite this being a serious issue, it is not necessary to restrict short selling to tackle it. A combination of strict settlement periods plus the mandating of heavy penalties for failures to settle would reduce or eliminate incentives not to settle. ${ }^{44}$

In popular sentiment the concerns highlighted here about short sales particularly manifest themselves about naked short selling as it can be conducted more aggressively than the conventional practice. ${ }^{45}$ Consequently regulators (including in the EU and US) often impose a distinct and more onerous regime for naked short sales than for conventional short sales. ${ }^{46}$ Despite such concerns however, naked short selling does not lend itself to stronger justifications for regulation; in terms of economic implications it is not a special case compared with conventional short selling. ${ }^{47}$

\footnotetext{
${ }^{43}$ FSA (n 14) 18.

${ }^{44}$ Emilios Avgouleas, 'The Vexed Issue of Short Sales Regulation When Prohibition Is Inefficient and Disclosure Insufficient?' in Kern Alexander and Niamh Moloney (eds), Law Reform and Financial Markets (Edward Elgar 2011) 92.

${ }^{45}$ Seraina N. Grunewald, Alexander F. Wagner and Rolf H. Weber, 'Short Selling Regulation after the Financial Crisis: First Principles Revisited' (2011) 7 International Journal of Disclosure and Governance 108, 117.

${ }^{46}$ See e.g. the imposition of an emergency ban with respect to naked short selling of particular financial institutions by the SEC during the crisis, SEC, 'Emergency Order Pursuant to Section 12(K)(2) of the Securities Exchange Act of 1934 Taking Temporary Action to Respond to Market Developments, Release No. 58166' (15 July 2008).

${ }^{47}$ See e.g. Christopher L. Culp and J. B. Heaton, 'The Economics of Naked Short Selling' (2008) 31 Regulation 46 who elaborate on the near economic equivalence between naked and covered short selling.
} 
First, although settlement disruption is more likely with naked than conventional short sales, clearing agencies generally have systems in place to tackle any such delays. Similarly, any abusive naked shorting behaviour is likely to already be prohibited under existing market manipulation legislation. Next, turning to its benefits, in line with covered short selling, naked short selling contributes to market efficiency. Indeed, naked short selling can in particular be employed by market makers and other liquidity providers to quickly and efficiently fill orders, and can provide liquidity when it is otherwise scarce. ${ }^{48}$

In light of this discussion, it is clear that the real rationale behind the crisis-era short selling temporary bans (both naked and covered) stemmed especially from the pressure faced by securities' regulators during the crisis. Specifically, the authorities utilised short selling restrictions as a technique for trying to ensure financial stability (especially with respect to financial institutions). ${ }^{49}$ Further, it was also clear that, as Enriques observes, doing nothing was not an option; the sense of panic required everyone to be seen to be acting to prevent it, and it would have been very embarrassing for the regulators to admit there was nothing they could do to avoid a meltdown. ${ }^{50}$ Indeed, such explanations also hold true when one reflects on the recent actions taken by the Chinese and the Greek regulators. Temporary short selling restrictions were imposed as a means to try and restore financial stability: the

\footnotetext{
${ }^{48}$ See e.g. Veljko Fotak, Vikas Raman and Pradeep Yadav, 'Naked Short Selling: The Emperor's New Clothes' American Finance Association Denver Meetings Paper (2010) <http://papers.ssrn.com/sol3/papers.cfm?abstract_id=1573163> accessed 19 November 2012.

${ }^{49}$ Moloney (n 2) 540-1.

${ }^{50}$ Luca Enriques, 'Regulators' Response to the Current Crisis and the Upcoming Reregulation of Financial Markets: One Reluctant Regulator's View' (2009) 30 University of Pennsylvania Journal of International Law 1147, 1148.
} 
constraints could be swiftly introduced; they were easy to sell to the public; and they demonstrated the regulators were taking action to try and control the situation. ${ }^{51}$

\section{Permanent Short Sale Restrictions}

Generally speaking, when there is a perceived need for regulation, there are a number of tools that can be used with respect to short selling: permanent and temporary restrictions; reporting requirements; and settlement rules. All such tools are now utilised in the EU's and the US's regulatory regimes to a greater or lesser extent, although at the heart of both regimes is a range of short selling restrictions. This section examines the EU and US permanent restrictions on short selling. It illustrates that functional similarities exist as both jurisdictions have imposed a de facto permanent ban on naked short sales. Clear divergences are also evident however. In particular, the EU has gone further than the US in also permanently restricting the short selling of sovereign debt and prohibiting the use of naked sovereign CDSs to effect a short position.

1. The EU

(a) Introduction

It often takes a financial crisis or a scandal to trigger regulatory change,${ }^{52}$ and in the EU, the financial and sovereign debt crises heralded in an enormous swathe of

\footnotetext{
${ }^{51}$ Moloney (n 2) 540-1.
} 
reforms characterised by greater harmonisation; further centralisation of powers at the European level and an expansion of the regulatory perimeter. In particular the early post-crisis European reform agenda was primarily focused on ensuring financial stability and the opportunity was also taken with many of the early reforms to regulate actors and practices perceived to be a threat to financial stability, including regulating short selling. ${ }^{53}$

Although short selling came into the limelight during the financial crisis, short selling regulation did not then form a key component of the G20's post-crisis reform agenda. ${ }^{54}$ Nevertheless at the EU level, CESR started to investigate further convergence with respect to short selling, launching a review of policy in July 2009 with a view to formulating pan-European standards on short selling. ${ }^{55}$ Additionally, following the implementation of various unilateral and uncoordinated short selling bans during the financial crisis, there were calls from the Council in early 2009 to enhance greater convergence between Member States with respect to short selling measures. ${ }^{56}$

\footnotetext{
${ }^{52}$ For instance following the global problems triggered by Enron and WorldCom's accounting scandals, the US adopted the Sarbanes-Oxley Act in 2002. Likewise, in the UK, the Financial Services and Markets Act 2000 was adopted in response to various financial flaws arising in the late 1990s. See e.g. Roberta Romano, 'The Sarbanes-Oxley Act and the Making of Quack Corporate Governance' (2005) 114 The Yale Law Journal 1521; Peter Yeoh, 'Hedge Funds: From Privileged Child to Locust and Now Bogeyman?' (2012) 33 Company Lawyer 42.

${ }^{53}$ Niamh Moloney, 'Reform or Revolution? The Financial Crisis, EU Financial Markets Law, and the European Securities and Markets Authority' (2011) 60 ICLQ 521, 524.

${ }^{54}$ Moloney (n 2) 542.

${ }^{55}$ CESR, 'CESR Proposal for a Pan-European Short Selling Disclosure Regime' (July 2009); CESR, 'Report: Model for a Pan-European Short Selling Disclosure Regime' (March 2010).

${ }^{56}$ Council of the European Union, Press Release: Economic and Financial Affairs (10 February 2009) 12. The Council also supported CESR's on-going work in this regard.
} 
The issue of short selling then became subsequently entwined in the negotiations surrounding the contentious Alternative Investment Fund Managers Directive ('AIFMD'). ${ }^{57}$ Specifically, during the financial crisis, a negative association had emerged between hedge fund activity and short selling. This was especially due to the shorting activity of hedge funds that was popularly perceived to have amplified the severe price falls. Consequently, in terms of the subsequent AIFMD negotiations, the Parliament in particular took a very hostile view of naked short selling, proposing that it be banned throughout the EU. ${ }^{58}$

The onset of the European sovereign debt crisis then reignited political concerns about short selling. In particular, the German and French Governments accused speculators of using naked sovereign CDSs to exacerbate the fiscal problems of many euro-area countries through raising governments' borrowing costs. President Sarkozy and Chancellor Merkel wrote to the Commission on more than one occasion questioning the impact of speculative naked sovereign CDSs on bond yields, and proposing legislative measures banning such practices. ${ }^{59}$ In May 2010, Germany also then shocked the markets with its unilateral prohibition on the naked short selling of sovereign debt and sovereign CDS on euro-area government bonds. ${ }^{60}$

\footnotetext{
${ }^{57}$ For detailed discussion, see e.g. Eilís Ferran, 'After the Crisis: The Regulation of Hedge Funds and Private Equity in the EU' (2011) 12 EBOR 379.

${ }^{58}$ European Parliament Committee on Economic and Monetary Affairs, Report on the Proposal for a Directive on Alternative Investment Fund Managers (A7-0171/2010) 12-13; Moloney (n 2) 544.

${ }^{59}$ See e.g. Stephen Fidler, 'What Sarkozy, Merkel Wrote on CDS' The Wall Street Journal (11 March 2010); Nicolas Sarkozy and Angela Merkel, Letter to President of the European Commission (8 June 2010).

${ }^{60}$ See e.g. Tony Barber and Gerrit Wiesmann, 'Berlin Makes Shock Move without Allies' Financial Times (20 May 2010); Harry Wilson, 'Markets Crash as German Short--Selling Ban Bites' The Telegraph (19 May 2010).
} 
Despite the Franco-German concerns however, there was little concrete evidence to substantiate their allegations. In particular, a report by the Commission's own Task Force found there was no conclusive evidence that developments in the sovereign CDS market had led to higher funding costs for Member States. ${ }^{61}$ Likewise, research undertaken by the IMF concluded that, overall, the evidence did not support the need to ban purchases of naked sovereign CDSs. ${ }^{62}$

In addition, given that it was countries such as Greece and Portugal whose sovereign bond markets were most affected by any alleged speculation, one might have expected it to be them, rather than France and Germany to be arguing most ardently for the imposition of short selling restrictions. With this in mind, the Franco-German actions were perhaps suggestive of politicians' attempts to utilise the debt crisis to further their own interests. ${ }^{63}$ For instance, French presidential and German state elections were on the horizon and taking a hard stance on speculative short sellers was likely to prove popular with the voters, whilst also deflecting blame from the politicians' own shortcomings. ${ }^{64}$

More broadly, it is also notable that the Franco-German practice of sending out joint communications with shared priorities also extended beyond short selling regulation

\footnotetext{
61 Commission, 'Task Force Report on Sovereign CDS' <http://online.wsj.com/public/resources/documents/ReportonsovereignCDS12072010.pdf (http://perma.cc/6YFM-4ATV)> accessed 20 August 2013. See also e.g. Oscar Arce, Sergio Mayordomo and Juan Ignacio Peña, 'Credit-Risk Valuation in the Sovereign CDS and Bonds Markets: Evidence from the Euro Area Crisis' (2013) 35 Journal of International Money and Finance 124. See also Alessandro Fontana and Martin Scheicher, 'An Analysis of Euro Area Sovereign CDS and Their Relation with Government Bonds’ (ECB Working Paper, December 2010).

${ }^{62}$ See IMF, A New Look at the Role of Sovereign Credit Default Swaps (April 2013).

${ }^{63}$ Eilis Ferran, 'Crisis-Driven Regulatory Reform: Where in the World Is the EU Going?' in The Regulatory Aftermath of the Global Financial Crisis (Cambridge University Press 2012), 30.

${ }^{64}$ Ibid 29-30; 'Banning Naked Short-Selling Won't Solve the Eurozone Crisis' The Guardian (6 July 2012).
} 
to wider areas of reform. ${ }^{65}$ For instance, in May 2010 the Franco-German leaders wrote to Commission President Barroso attacking the credit rating agencies for their role in the sovereign debt crisis and calling for tough measures to be taken to curb their influence in the markets. ${ }^{66}$ With this in mind, it has been suggested that such practices provided evidence of the emergence of a more intrusive regulatory style that reflected Franco-German choices. ${ }^{67}$ Although in the pre-crisis era the British 'light touch' and 'disclosure focused' policymakers had been especially influential at the European level, this had been discredited since the start of the crisis, paving the way for the rise of a new pecking order within the EU. ${ }^{68}$ This involved a more stabilityorientated approach to regulation that included the use of trading bans as a regulatory tool; an approach associated especially with France, and Italy, and, to a lesser extent, with Germany. ${ }^{69}$

In this very tense political atmosphere, the Commission produced a short selling proposal (along with its European Market Infrastructure Regulation proposal ('EMIR') with respect to regulating OTC derivatives) in September $2010 .^{70}$ The short selling proposal was less interventionist than the final set of rules, and the proposal was subject to a series of highly charged and drawn-out negotiations. ${ }^{71}$ In particular, along with the Franco-German demands, the Parliament was especially vocal in pushing for a ban on naked short selling, including in relation to naked sovereign

\footnotetext{
${ }^{65}$ Eilis Ferran (n 63) 30.

${ }^{66}$ See e.g. Tony Barber and Tom Braithwaite, 'European Leaders Hit at Ratings Agencies' Financial Times (London, 7 May 2010).

${ }^{67}$ See e.g. Lucia Quaglia, 'The 'Old' and 'New' Political Economy of Hedge Fund Regulation in the European Union’ (2011) 34 West European Politics 665, 667; Eilis Ferran (n 63) 29-30.

${ }^{68}$ Quaglia (n 67) 677-8; Eilis Ferran (n 63) 29.

${ }^{69}$ Eilis Ferran (n 63) 29. See also Quaglia (n 67).

${ }^{70}$ Moloney (n 2) 544-5.

${ }^{71}$ Ibid 545-6.
} 
CDSs (although the Parliament was also softer in its approach in some respects, including, for instance, with respect to the notion of a covered sovereign CDS trade)..$^{72}$

The outcome of the negotiations was a Regulation that contained one set of restrictions on the naked short selling of shares, and another lesser set of constraints on the naked short selling of sovereign debt. There was no economic justification behind the distinction in treatment of shares and sovereign debt: only political sensitivities with respect to Member States' sovereign debt markets explained the differentiation. In addition, particularly reflecting the Parliament's input (in conjunction with the input of a number of Member States), an effective ban was also imposed on naked sovereign CDSs (although the Parliament eventually had to concede to an opt-out provision). ${ }^{73}$ The Regulation's politicisation was also further evidenced in the absence of regulation on the short selling of corporate bonds. ${ }^{74}$

(b) Overview of the Regulation

To provide a brief overview of the EU rules, the Regulation's scope is widely drawn; domicile or establishment is irrelevant, and the territorial scope is defined by the nature of the instrument traded not a person's location. ${ }^{75}$ Consequently the rules have

\footnotetext{
${ }^{72}$ See e.g. European Parliament, Report on the Proposal for a Regulation of the European Parliament and of the Council on Short Selling and Certain Aspects of Credit Default Swaps (19 April 2011).

${ }^{73}$ See e.g. Margarida Vasconcelos, Ban on Naked CDS on Sovereign Debt Is a Victory for the European Parliament and a Blow to the UK (October 2011).

${ }^{74}$ See e.g. Economic and Financial Affairs Council (ECOFIN), Short Selling Proposal: Progress Report (November 2010) where some delegations raised their opposition to the inclusion of sovereign debt instruments but there was no discussion as to the regulation of corporate bonds; see also e.g. Economic and Financial Affairs Council (ECOFIN), Proposal for a Regulation of the European Parliament and of the Council on Short Selling and Certain Aspects of Credit Default Swaps-Revised Presidency Compromise 6823/1/11 (4 March 2011).

${ }^{75}$ ESMA, 'Questions and Answers: Implementation of the Regulation on Short Selling and Credit Default Swaps (2nd Update) 2013/159’ (January 2013), question 1a.
} 
extra-territorial scope when short-selling activities relate to 'in-scope' instruments. ${ }^{76}$ However despite its wide ambit, the restrictions are then largely directed at shares, sovereign debt, and uncovered sovereign CDSs. ${ }^{77}$ Strict settlement rules are also imposed, ${ }^{78}$ and, accompanying the restrictions, are a set of reporting requirements in relation to net short positions. ${ }^{79}$ Private and public reporting is required of short sales of shares, although only private notifications are required of sovereign debt. Further, in exceptional circumstances a wide set of temporary intervention measures can be imposed by NCAs, and, potentially, also by ESMA. ${ }^{80}$

There are a number of supervisory and enforcement mechanisms under the Regulation that include NCA supervisory and investigatory powers; wide powers are also conferred on ESMA that range from it performing a facilitation and coordination role with respect to NCA emergency measures, to ESMA's own direct intervention powers. ${ }^{81}$ In terms of ex post sanctions, the Regulation's provisions largely reflect the pre-crisis 'less articulated' approach to enforcement. ${ }^{82}$ Penalties for infringements are not harmonised and it is up to the Member State to establish rules on the measures applicable. ${ }^{83}$ However on an annual basis, Member States are required to provide

\footnotetext{
${ }^{76}$ Moloney (n 2) 551.

${ }^{77}$ Council Regulation (EU) 236/2012 of the European Parliament and of the Council of 14 March 2012 on Short Selling and Certain Aspects of Credit Default Swaps [2012] OJ L86/1, arts 12-14.

${ }^{78}$ Ibid art 15.

${ }^{79}$ Ibid arts 5-7.

${ }^{80}$ Ibid arts 18-23, art 28.

${ }^{81}$ Ibid arts 27-40.

${ }^{82}$ Moloney (n 2) 570.

${ }^{83}$ Ibid 570, 967.
} 
ESMA with aggregate information regarding penalties and administrative measures imposed. ${ }^{84}$

Overall, the NCAs and ESMA should be able to encourage compliance with the Regulation through a range of strategies including ex ante supervision, monitoring and voluntary compliance techniques, to more punitive enforcement mechanisms in the event of a firm's non-compliance (a 'pyramid of sanctions'). ${ }^{85}$ Further, although the penalties for infringements are not harmonised in the Regulation, change can now be observed more broadly with the related European market abuse reforms that take effect in July 2016. The new rules adopt a more prescriptive approach to penalties, including providing minimum standards with respect to sanctions for specific breaches of the revised market abuse rules. ${ }^{86}$ Consequently, it may become easier going forward to impose harmonised sanctions under the linked market abuse legislation.

(c) Permanent Restrictions: Uncovered Short Selling of Shares

Examining the Regulation's permanent restrictions, the core provisions are geared towards the short sale of securities, sovereign debt, and sovereign CDSs. ${ }^{87}$ The

\footnotetext{
${ }^{84}$ Regulation 236/2012, art 41.

${ }^{85}$ See e.g. Robert Baldwin and Julia Black, 'Really Responsive Regulation' (2008) 71 Modern Law Review 59, 60-63. Nevertheless, Baldwin and Black also observe that there are various conceptual, practical, and principled drawbacks to the pyramid approach

${ }^{86}$ The UK has currently opted out with respect to the rules relating to criminal sanctions as the UK regime already provides for criminal sanctions for market abuse offences although it may opt-in going forward.

${ }^{87}$ As will be observed in section D.2 below, the EU constraints are, in part, based on the US restrictions where a 'locate' rule also forms part of its regulatory set-up. The EU provisions are also in line with the IOSCO high-level principles on short selling. IOSCO specified that regulators could reinforce their regulatory regime by adopting other criteria including a locate requirement, IOSCO (n 24) 10 .
} 
Regulation draws a fundamental distinction between naked and covered short selling, and while naked short selling is subject to a strict set of constraints, a lighter set of rules (predominantly based around reporting requirements) apply to covered short sales. The permanent restrictions apply to the naked short selling of shares but notably they do not extend to 'synthetic' short sales, such as through the use of derivatives. It is likely that options and other synthetic strategies were not included in the main restrictions due to the fact that the public found short selling morally reprehensible but did not understand the use of more complex strategies such as put and call options.

Article 12 distinguishes between covered and naked short sales and provides that a natural or legal person ('person') may enter into a short sale of shares admitted to a trading venue in the EU when it is regarded as covered. This requires one of three conditions to be met. First, a short sale is covered if the shares have been borrowed or alternative provision has been made to the same effect. ${ }^{88}$ Alternatively, it is regarded as covered if a person has entered into an agreement to borrow the share or has another 'absolutely enforceable claim' under contract or property law to be transferred ownership of a corresponding number of securities of the same class so settlement can be effected when due. ${ }^{89}$ The Implementing Regulation elaborates on the type of agreements contemplated, including futures and swaps contracts, options and repurchase agreements. ${ }^{90}$ Securities lending and prime brokerage arrangements

\footnotetext{
${ }^{88}$ Regulation 236/2012, art 12(1)(a).

${ }^{89}$ Ibid art 12(1)(b).

${ }^{90}$ Commission Implementing Regulation (EU) 827/2012 [2012] OJ L251/11, art 5(1)(a)-(f).
} 
are also capable of being employed but only if they are specific as to the number of shares being sold short and specify a delivery date..$^{91}$

Finally, a short sale is covered if it satisfies the 'locate' requirement. This rule was much fought over during the Regulation's negotiations and was eventually watered down from a 'hard locate and reserve' requirement as part of the trade-off for the Parliament obtaining its ban on naked sovereign CDSs. However although this concession was important politically, the amended rules still largely amount to a de facto ban on naked short selling. Specifically, the Regulation's locate rule requires that a person has an arrangement with a third party under which the third party has confirmed the share has been located, and has taken 'measures' vis-à-vis third parties necessary for the person to have a 'reasonable expectation' that settlement can be effected when due. ${ }^{92}$ The locate requirement is necessary in all cases before a short sale is undertaken and relates to the third party's confirmation that it can make the shares available for settlement in due time taking account of the amount of the possible sale and market conditions, and indicates the periods for which the shares are located.

The administrative rules then provide for three different confirmations and measures: a standard requirement, and lighter requirements imposed on intraday short sales, and liquid short sales. ${ }^{93}$ Broadly, for liquid short sales, and intraday short sales, an additional confirmation is required prior to the short sale being entered into that the share is easy to borrow or purchase in the relevant quantity, taking account of the

\footnotetext{
${ }^{91}$ Ibid, art 5(1)(f).

${ }^{92}$ Regulation 236/2012, art 12(1)(c).

${ }^{93}$ Implementing Regulation 827/2012, art 6.
} 
market conditions and other information available to the third party. ${ }^{94}$ ESMA has also confirmed that it is not possible to rely on or refer to easy to borrow lists; a precise confirmation is required. ${ }^{95}$ If such prior confirmations can be obtained, then the requested number of shares need not also be put on hold for that person. ${ }^{96}$ For all other 'standard' arrangements, the third party is required to confirm, prior to the short sale being entered into, that it has at least put on hold the requested number of shares for that person. ${ }^{97}$ Finally, the third party with whom the arrangements are made must be a distinct legal entity from the short seller. ${ }^{98}$

The EU provisions significantly constrain the practice of short selling. First, rather than, for instance, limiting their application to those situations where naked short selling could potentially give rise to the greatest likelihood of abuse; the restrictions apply to all shares within the Regulation's ambit, all of the time. Second, the restrictions are particularly onerous due the restrictive interpretation taken to the related administrative rules. For instance, commonly used master lending agreements will be incapable of satisfying the requirements unless they contain a specific confirmation covering specific securities and specifying a delivery date for each short sale. Next, the 'standard' locate confirmation and measures constitute a clear ban on naked short selling due to the put on hold requirement. Further, the rules on intraday and liquid short sales also amount to serious constraints. Short sellers cannot rely on

\footnotetext{
${ }^{94}$ Ibid art 6(3) and (4). Other confirmations are also specified including (for intraday purchases) a request for confirmation from the short seller to the broker that the short sale will be covered by purchases during the day; and undertakings by the short seller to monitor the amount of the short sale not covered by purchases.

${ }^{95}$ ESMA (n 75) 25.

${ }^{96}$ ESMA, 'Draft Technical Standards on the EU Short Selling Regulation: Final Report' (March 2012) 6.

${ }^{97}$ Implementing Regulation 827/2012, art 6(2).

${ }^{98}$ Ibid art 8 . Note that there are also limited exemptions from the restrictions for market-makers, Regulation 236/2012, art 17.
} 
easy to borrow lists and must obtain an actual confirmation from a broker before entering into the short sale that the share is easy to borrow in the relevant quantity taking account of market conditions. There are also additional confirmations and undertakings that have been described as 'superfluous and counterproductive'. 99

A 2013 evaluation of the regulation by ESMA (the 'Evaluation') also helps shed light on the rules' operation in practice. Although a degree of caution must be taken with the findings given the short time scale between the Regulation's introduction and its publication, ESMA's findings largely suggest that the restrictions have adversely affected the price discovery process and that the rules have negatively impacted activity in the securities lending market. ${ }^{100}$

Ultimately, it is the precise parameters of the locate arrangements and measures that determine how close a set of rules come to constituting an absolute ban on naked short selling. ${ }^{101}$ Specifically, due to the narrow interpretation of the permissible borrowing and locate arrangements, the European rules effectively amount to a de facto ban on naked short selling. Although watering down the 'hard locate' requirement during the negotiations was important politically, it has not resulted in a meaningful change.

\section{(d) Settlement Discipline}

\footnotetext{
${ }^{99}$ See e.g. German Banking Industry Committee, ESMA Call for Evidence (15 March 2013) 6.

${ }^{100}$ ESMA, 'Technical Advice on the Evaluation of Regulation (EU) 236/2012 on Short Selling and Certain Aspects of Credit Default Swaps' (June 2013) 72-74. Note however that the related introduction of banking liquidity regulations post-crisis might also have reduced financial firms' ability to engage in securities lending.

${ }^{101}$ John Armour and others, Principles of Financial Regulation (Draft Version) (OUP forthcoming 2016) ch 8, 19.
} 
Linked to the restrictions, are the settlement discipline rules whose function is to tackle the risk of settlement failure that arises particularly from naked short selling. These rules will only be touched on briefly as they are in the process of being replaced by the European Regulation on securities settlement and central securities depositories (the 'CSD Regulation'). ${ }^{102}$

The Regulation sets out basic standards of settlement discipline through a combination of buy-in procedures and fines for failed settlement of transactions in shares. ${ }^{103}$ The rules' ambit is limited however; they only cover shares cleared by central counterparties ('CCPs') so the rules do not extend to OTC or exchange transactions not cleared by CCPs. Further, the rules do not harmonise the length of the settlement periods throughout the EU and the settlement penalties are not harmonised, creating a risk of arbitrage. ${ }^{104}$

Settlement discipline requirements are now tackled through the CSD Regulation. The CSD Regulation aligns the settlement periods for transactions in transferable securities (broadly shares and bonds) executed on trading venues to $\mathrm{T}+2$. It also introduces mandatory buy-in periods where there are fails-to-deliver ('FTDs') within four business days after the intended settlement date. ${ }^{105}$ If buy-in is not possible, a party can choose to be compensated in cash or can defer execution until a later date.

\footnotetext{
${ }^{102}$ Regulation (EU) No 909/2014 of 23 July 2014 on Improving Securities Settlement in the European Union and on Central Securities Depositories and Amending Directives 98/26/EC and 2014/65/EU and Regulation (EU) No 236/2012 [2014] OJ L257/1.

${ }^{103}$ Regulation 236/2012, art 15.

${ }^{104}$ ESMA (n 100) 25.

${ }^{105}$ This is extended to 15 days for instruments traded on small and medium sized enterprise ('SME') markets.
} 
The CSDs must also establish procedures providing for penalties calculated on a daily basis, including cash penalties, to serve as a deterrent. ${ }^{106}$

The new rules are a welcome development and should help improve levels of settlement discipline within the EU going forward. They are also a sensible means of tackling concerns in relation to short selling and settlement disruption and should eliminate or reduce any incentive to fail to settle a trade. Nevertheless, many of the technical nuts and bolts of the CSD Regulation are still in the process of being finalised, and the settlement discipline measures and the related repeal of the short selling settlement rules will only apply from the entry into force of the related administrative rules on settlement discipline (currently anticipated for 2018). ${ }^{107}$

(e) Permanent Restrictions: Sovereign Debt Markets

\section{Sovereign Debt}

At a broad level, similar constraints to those imposed on shares dictate whether a short sale of sovereign debt is 'covered' and thereby permitted by the rules. ${ }^{108}$ Notably however, due to the political sensitivities surrounding possible damage to countries' sovereign debt markets, the sovereign debt restrictions are less onerous than those imposed on securities. For example, in contrast to the locate rule for shares that can require a put on hold confirmation, no such requirement is included for

\footnotetext{
${ }^{106}$ CSD Regulation art 7(2).

${ }^{107}$ Ibid arts 72 and 76(5); ESMA, 'Draft Regulatory Technical Standards on Settlement Discipline (Final Report)' (1 February 2016) 37.

${ }^{108}$ Regulation 236/2012, art 13.
} 
sovereign debt. ${ }^{109}$ The constraints also do not apply where the transaction serves to hedge a long position in an issuer's debt instruments, the pricing of which has a 'high correlation' with the pricing of the sovereign debt. ${ }^{110}$ This means a correlation of 80 per cent. Again, due to political concerns that the restrictions could affect the management of countries' budget deficits, ${ }^{111}$ an opt-out was agreed; the restrictions can be temporarily suspended by the NCA where the liquidity of the sovereign debt drops below a specified level. ${ }^{112}$

\section{Sovereign CDSs}

With respect to the rules governing uncovered sovereign CDSs, these provisions were particularly controversial during the Regulation's negotiations. The final rules are complex, reflecting the Parliament's push to ban such instruments, yet also trying to ensure that legitimate hedging activity continues to be permissible. The Regulation provides that a person may enter into an uncovered position in a sovereign CDS only where this does not lead to an uncovered position in a sovereign CDS. ${ }^{113}$ The provisions specify that whether the transaction is uncovered depend on whether it is a permitted hedge. ${ }^{114}$ There are two forms of permissible hedging. First, hedging is permitted against the risk of default of the issuer where the person has a long position in the sovereign debt of the issuer to which the sovereign CDS relates. Second,

\footnotetext{
${ }^{109}$ Implementing Regulation 827/2012, art 7(2).

${ }^{110}$ Regulation 236/2012, art 13(2).

${ }^{111}$ Commission, 'Short Selling: Technical Standards - Frequently Asked Questions' (2012) 3.

${ }^{112}$ Regulation 236/2012 art 13(3). Such a suspension is valid for six months but can be renewed. See further Commission Delegated Regulation (EU) 918/2012 [2012] OJ 274/1, art 22 for the detailed administrative rules for calculating and determining the threshold of liquidity for suspending the rules.

${ }^{113}$ Regulation 236/2012, art 14(1).

${ }^{114}$ Ibid art 4(1).
} 
'proxy' hedging is permitted against the risk of a decline of the value of the sovereign debt where the person holds assets or is subject to liabilities (including, but not limited to financial contracts, a portfolio of assets, or financial obligations) the value of which is correlated to the value of the sovereign debt. ${ }^{115}$

Due to the challenge of distinguishing legitimate and illegitimate hedging, the related administrative provisions set out a complex regime that must be complied with to constitute a permissible hedge. ${ }^{116}$ A broad range of exposures can be hedged, but cross-border hedging is not generally permissible. ${ }^{117}$ Although there were considerable differences of view when the administrative provisions were being drafted as to whether cross-border hedging should be permissible, a member of ESMA's board of supervisors was quoted as saying that it had received a very strong position that cross-border hedging was not exempt. ${ }^{118}$ This outcome can be questioned however; there may be several legitimate reasons for hedging a risk in one Member State with a sovereign CDS related to a reference entity in another Member State (including where, for instance, cheaper proxies exist). ${ }^{119}$ Further, such restrictions may also contradict core principles behind the EU's single market and could provide disincentives in relation to cross-border business.

\footnotetext{
${ }^{115}$ Ibid art 4(1).

${ }^{116}$ Delegated Regulation 918/2012, recital 6.

${ }^{117}$ Ibid, see art 15 for the limited exceptions.

118 'Short Selling and CDS Regulation in EU: Less to Nakedness Than Meets the Eye, Funds and Firms Argue' Reuters (5 March 2012) 2. Indeed, when one considers the Regulation's wording, it does not explicitly state that hedging can only be in one Member State. Article 4 is silent on the issue and recital 21 provides examples of a wide range of exposures that could be eligible.

${ }^{119}$ Likewise, the restrictions will also preclude using European sovereign CDS indices for general EU risks that do not include all Member States or pan-euro Member States in the index, see e.g. Deutsche Bank, ESMA Call for Evidence (15 March 2013) 9.
} 
Next, correlation is also a key test to eligibility, and alternative quantitative or qualitative tests are set out in the administrative rules. Broadly, the quantitative test is met where there is a correlation coefficient of at least 70 per cent between the price of the assets or liabilities being hedged and the price of the sovereign debt. This is calculated on a historical basis for at least 12 months of trading days preceding when the CDS position was taken out. The qualitative test shall be met showing a 'meaningful' correlation based on 'appropriate' data. This should again be calculated on a historical basis but an alternative time frame can be used if it would reflect similar conditions to those at the time the CDS position was taken out. ${ }^{120}$ Finally, there is also a proportionality requirement: the size of the sovereign CDS position must be proportionate to the size of the exposure being hedged. ${ }^{121}$

Although the quantitative test is precise, the requirement that the calculation be made on a historical basis fails to take into account that correlation may change over time or may not yet exist with respect to situations of legitimate hedging of future risks. ${ }^{122}$ Likewise, it is also unclear what will be sufficient to satisfy the qualitative test. Although this has likely been included to ensure parties can capture a broader range of assets, it could prove risky to rely on in practice. For instance, where a party is required to justify to the regulator that the test has been met, the ban could be breached if they cannot demonstrate that the data they relied on was appropriate. ${ }^{123}$

\footnotetext{
${ }^{120}$ Delegated Regulation 918/2012, art 18.

${ }^{121}$ Ibid art 19. A perfect hedge is not required however.

${ }^{122}$ AFME and ISDA, ESMA Call for Evidence (15 March 2013) 36. This means in general it will not be possible to hedge against 'tail risk' events (i.e. although some assets will not be correlated with a sovereign CDS on a daily basis, it would be expected to have a high level of correlation if there was a tail risk event such as severe market turmoil).

${ }^{123}$ Credit Suisse, 'The Regulation on Short Selling and Certain Aspects of CDS' (Fixed Income Research, October 2012) 8; Travers Smith, Short Selling: Remember, Remember the First of November (26 October 2012) 3 .
} 
Due to uncertainties surrounding the provisions' application, parties will likely avoid using sovereign CDSs and shift to other mechanisms, and this has been borne out in practice. ${ }^{124}$ From August 2011 onwards, volumes of net notional CDSs started to sharply decline and this could have been in part due to positions being unwound in advance of the Regulation's introduction. ${ }^{125}$ Some parties indicated positions were being unwound, as it was feared the hedging rules were so vague that they would be viewed as speculating even if they were not. ${ }^{126}$ There has also been a sharp decline in volumes traded on the European sovereign CDS indices (CDS contracts on a basket of reference entities are known as 'index and tranche CDS' and combine reference entities with a theme in common). ${ }^{127}$ In addition, since the Regulation came into force, volumes traded on the main European sovereign CDS index have declined 100 per cent (i.e. the index has essentially been shut down). ${ }^{128}$

Finally, the EU rules also provide for an opt-out in the event that the CDS restrictions increase the cost of borrowing. ${ }^{129}$ There is a paradox here as it is precisely at the time when the opt-out powers can be exercised that regulators may be restricting other forms of short selling. ${ }^{130}$ As with the ability to suspend the sovereign debt restrictions, this opt-out provision was the product of political compromise during the negotiations. Indeed, it serves to reiterate that the political reality of the rule-making

\footnotetext{
${ }^{124}$ For instance, since the Regulation came into effect, open interest on sovereign bond futures has increased, especially for French and Italian bonds, see ESMA (n 100) 94.

${ }^{125}$ Ibid (n 100) 90.

${ }^{126} \mathrm{IMF}(\mathrm{n} 62) 17$.

${ }^{127}$ IOSCO, 'The Credit Default Swap Market Report' (June 2012) 12.

${ }^{128}$ Deutsche Bank (n 119) 9.

${ }^{129}$ Regulation 236/2012, art 14(2).

${ }^{130}$ Oskari Juurikkala, 'Credit Default Swaps and the EU Short Selling Regulation: A Critical Analysis' (2012) 9 ECFR 307, 337-8.
} 
process can lead to ambiguities and internal inconsistencies within the legislation itself. In this instance, most of the countries that opposed the Parliament's sovereign CDS restrictions, eventually agreed after this provision was included. ${ }^{131}$

\section{The US: Permanent Restrictions on Short Sales of Shares}

(a) Introduction

In contrast to the EU, the US did not introduce short selling restrictions in the sovereign debt market. In particular, as Moloney observes, although there was some initial discussion about an international G20 response to CDS trading, including in relation to the sovereign debt markets, the international reform agenda then shifted away from short selling regulation and become more focused on the regulation of OTC derivatives and related clearing obligations. ${ }^{132}$

Nevertheless, in the light of the financial crisis, the SEC subsequently introduced a number of additional short selling constraints with respect to equity securities, and a variety of different provisions now restrict short selling in the US. As this section will illustrate, the naked short selling rules in place in the US are functionally equivalent to those in the EU, and amount to a de facto ban on naked short selling. However, the

\footnotetext{
${ }^{131}$ In particular Spain and Italy were opposed to the CDS ban but ultimately agreed after the opt-out was included. The UK campaigned against the rules but was ultimately out-voted however, see Vasconcelos (n 73); Helia Ebrahimi, 'EU Set to Ban Insurance on Sovereign Bonds' The Telegraph (18 October 2011). See also e.g. 'EU Short-Selling Talks Collapse Amid Sovereign Debt Fears' EurActiv (22 September 2011).

${ }^{132}$ Moloney (n 2) 542; Nikki Tait, Ben Hall and David Oakley, 'Policing of CDS Trading Poses Dilemma' Financial Times (9 March 2010).
} 
US has also gone further than the EU in imposing restrictions on both covered and naked short selling in advance of seasoned equity offerings ('SEO'). ${ }^{133}$

Additionally, as with the EU's rules, the broader political context has also had a significant impact on the SEC's short selling policy. First, as observed in section A, although the SEC is an independent regulatory agency, it is also a political body. ${ }^{134}$ It is the President who appoints the SEC Commissioners and its Chairman; and it is the President and Congress who set the SEC's annual budget. ${ }^{135}$ Indeed, Congress maintains increasingly tight control over SEC policy, especially through the means of the budgetary process. ${ }^{136}$

Further, the SEC also became weakened as a regulatory agency during the financial crisis. Specifically, it became the subject of much criticism as to its performance, including with respect to its failures in relation to the Bernie Madoff Ponzi scheme fraud, ${ }^{137}$ and for its lack of supervision of the investment banks, most of which suffered turmoil during the crisis. ${ }^{138}$ The SEC also came under huge pressure from the

\footnotetext{
${ }^{133}$ Regulation M, rule 105 . As observed in section A, a SEO is a type of secondary share offering

${ }^{134}$ Sirri (n 20) 534.

${ }^{135}$ Langevoort, 'The SEC as a Lawmaker: Choices About Investor Protection in the Face of Uncertainty' 1598 (n 21); Donald Langevoort, 'Structuring Securities Regulation in the European Union: Lessons from the U.S. Experience' (Georgetown Law Faculty Research Paper, 2005) 20.

${ }^{136}$ Langevoort, 'The SEC and the Madoff Scandal: Three Narratives in Search of a Story' (n 21); Langevoort, 'The SEC as a Lawmaker: Choices About Investor Protection in the Face of Uncertainty' (n 21) 1598.

${ }^{137}$ This was despite the attempts of the Boston-based financial analyst Harry Markopolos who tried to convince the SEC to expose the Madoff scandal, plus a number of SEC investigations and inspections that also failed to identify the truth, Langevoort, 'The SEC and the Madoff Scandal: Three Narratives in Search of a Story' (n 21) 1-2.

${ }^{138}$ David P. McCaffrey, 'Review of the Policy Debate over Short Sale Regulation During the Market Crisis' (2009) 73 Alb L Rev 483, 514; Langevoort, 'The SEC and the Madoff Scandal: Three Narratives in Search of a Story' (n 21). See also e.g. Norman Poser, 'Why the SEC Failed: Regulators against Regulation' (2009) 3 Brooklyn Journal of Corporate, Financial \& Commercial Law 289. Poser suggests reasons for the SEC's various failures including conflicts of interest; lack of resources; inadequate staff training; and an ethos of de-regulation that prevailed pre-crisis.
} 
Treasury and the Federal Reserve, including with respect to the imposition of temporary short selling bans during the crisis, and a number of Congressmen also started demanding that the SEC carry out investigations into short selling practices. ${ }^{139}$ Consequently, when reflecting on the approach the SEC took to its short selling policy post-crisis, it may well have been influenced by the need to try and placate its political critics, especially those who provided its funding in order to maintain its jurisdiction going forward. ${ }^{140}$

In this regard however, it is also important to appreciate that this is only part of a more complex story. Specifically, the primary aims of the Federal Reserve and the Treasury include the more short-term goals of maintaining the financial system's stability and containing systemic risk. ${ }^{141}$ In contrast, the SEC's main objectives are more related to ensuring the efficiency and liquidity of financial markets and the efficient allocation of resources. ${ }^{142}$ Given that the Federal Reserve and the Treasury are more powerful governmental actors than the SEC, it is evident that in a time of

\footnotetext{
${ }^{139}$ Chairman Cox subsequently stated that he had come under intense pressure to impose the temporary short selling bans in 2008, see e.g. Rachelle Younglai, 'SEC Chief Has Regrets over Short-Selling Ban' Reuters (31 December 2008); Committee on Financial Services - Democrats, 'Barney Frank Letter to SEC Chairman Cox: Short Sales of Bear Stearns and Other Investment Bank Stock' (4 April 2008) <http://democrats.financialservices.house.gov/press110/press0404083.shtml> accessed 17 January 2014.

${ }^{140}$ Sirri (n 20) 535.

141 Federal Reserve, 'What Is the Purpose of the Federal Reserve System?' (2014) <http://www.federalreserve.gov/faqs/about_12594.htm> accessed 16 June 2015; US Department of the Treasury, 'Duties \& Functions of the U.S. Department of the Treasury' (2011) <http://www.treasury.gov/about/role-of-treasury/Pages/default.aspx> accessed 16 June 2015; Henry T. C. Hu, 'Too Complex to Depict? Innovation, "Pure Information," and the SEC Disclosure Paradigm' (2012) 90 Tex L Rev 1601, 1698-99.

${ }^{142}$ SEC, 'The Investor's Advocate: How the SEC Protects Investors, Maintains Market Integrity, and Facilitates Capital Formation' (2013) <http://www.sec.gov/about/whatwedo.shtml> accessed 16 June 2015; Hu (n 141) 1699. Indeed, the SEC had long been aware of the financial consensus as to the importance of short selling with respect to the efficiency of markets, see further Henry T. C. Hu, 'Efficient Markets and the Law: A Predictable Past and an Uncertain Future' (2012) 4 Annual Review of Financial Economics 179 that articulates the importance of market efficiency to the SEC's mission.
} 
crisis, the concrete aim of short-term stability would carry far more weight than the longer-term and more nuanced objective of market efficiency. ${ }^{143}$

(b) Permanent Restrictions on All Short Sales

The short selling restrictions now in place go beyond the EU's regime as the US rules also impose constraints on all short sales before a SEO. ${ }^{144}$ The current incarnation of the SEO rules provide that persons who opened a short position five days before the offer date are prohibited from purchasing shares in the offer, regardless of whether the shares would be used to cover the short sale. As observed in section A, broadly the economic literature suggests that there is only limited evidence as to manipulative shorting behaviour, and the scholarship also suggests that imposing short sale constraints could result in adverse consequences. ${ }^{145}$

As observed in Section $\mathrm{C}$, there are real and serious concerns that exist about manipulative behaviour, and this includes short selling behaviour in advance of SEOs. Nonetheless, it is also clear that the imposition of ex ante short selling restrictions will impede pricing efficiency, and can also restrict legitimate short selling activity. In addition, a number of factors unrelated to short selling may also affect a particular

\footnotetext{
${ }^{143} \mathrm{Hu}$, 'Efficient Markets and the Law: A Predictable Past and an Uncertain Future' (n 142) 193.

${ }^{144}$ The EU instigated no restrictions before a SEO but it did introduce a two-tier reporting regime. Detailed discussion of the reporting rules is beyond the scope of this article but the rules (in brief) include notifications to regulators of net short positions, triggered if the net short position reaches a particular threshold. In principle, such notifications offer a means of tracking short selling activities and provide early warning signals to regulators concerning the build up, and who owns, a short position (although it is unlikely that any 'abusive' short sellers will notify the regulator as to any manipulative behaviour occurring).

${ }^{145}$ See e.g. Kim and Shin (n 18); Jones, Reed and Waller (n 18). For an alternative view see e.g. Henry and Koski (n 18).
} 
offer's stability and its success. ${ }^{146}$ With this in mind, it may be preferable for regulators to seek to target any manipulative activity occurring through better enforcement of existing market abuse regimes rather than through imposing ex ante short sale restrictions.

\section{(c) Permanent Restrictions on Naked Short Sales}

Next, naked short sales are subject to a locate requirement under Regulation SHO. This was implemented in January 2005 and broker-dealers are required, prior to effecting a short sale in an equity security, (either for another person or for its own account), to locate securities available for borrowing. Broker-dealers are on the 'front line' with respect to short selling regulation and they must have either borrowed the security; entered into an arrangement to borrow the security; or have 'reasonable grounds' to believe the security can be borrowed so that it can be delivered on the date delivery is due. ${ }^{147}$ What constitutes reasonable grounds is not specified but a broker-dealer can receive assurance from a short seller that it can obtain the shares from another identifiable source in time to settle the trade. ${ }^{148}$ Further, the SEC has verified that easy to borrow lists can provide reasonable grounds provided the list is under 24 hours old and the securities on the list are readily available such that it would be unlikely a FTD would occur. ${ }^{149}$ Thus, in contrast to the EU provisions, the

\footnotetext{
${ }^{146}$ Emilios Avgouleas, 'Short-Sales Regulation in Seasoned Equity Offerings: What Are the Issues?' in Dan Prentice and Arad Reiserg (eds), Corporate Finance in the UK and EU (OUP 2011) 130-131.

${ }^{147}$ Regulation SHO, rule 203(b). Note that brokers must also document compliance with the locate requirement.

${ }^{148}$ SEC, 'Short Sales, Release No. 34-50103 (Final Rule)' (July 28, 2004), 48014.

${ }^{149}$ Ibid 48014.
} 
reasonable grounds test can be satisfied without having to supply evidence of firm confirmations and arrangements ahead of settlement. ${ }^{150}$

Regulation SHO also imposed additional delivery requirements on equity securities with substantial amounts of FTDs, ${ }^{151}$ however these provisions, and others, were then subsequently tightened in the light of the financial crisis. Indeed, particularly linked to the need for the SEC to be seen to be responding to the crisis, ${ }^{152}$ it embarked on a period of intensive rule making. For instance, between July 2008 and August 2009 the SEC took more than 15 regulatory actions with respect to short selling and many of these (related to its need to be perceived to be taking firm and decisive action) were adopted using emergency orders without the usual 'public notice and comment' process. ${ }^{153}$

First, in the context of naked short sales, the SEC's regulatory policy extended to encompass even tighter rules for FTDs. In particular, emergency FTD rules that were introduced by the SEC during the crisis were subsequently made permanent in July 2009. ${ }^{154}$ These provisions required shares to be delivered for settlement by $\mathrm{T}+3$, and, if the participant had a FTD, it had to be closed out by the morning after $(\mathrm{T}+4)$. If the

\footnotetext{
${ }^{150}$ Note that exceptions exist including in relation to market-making activities.

${ }^{151}$ Regulation SHO, rule 203(b)(3). Equity securities with substantial amounts of FTDs were known as 'threshold securities'. To be deemed such a security, there had to be an aggregate FTD for five consecutive settlement days at a registered clearing agency of 10,000 shares or more and that was equal to at least 0.5 per cent of an issuer's outstanding shares. It was also required to be included on a list disseminated by a self-regulatory organisation. If a clearing agency participant had a FTD in a threshold security for 13 consecutive days, then until it was closed out, participants, and broker-dealers for which it cleared transactions for, could not accept or effect a short sale without complying with the 'pre borrowing' requirement, see SEC, 'Short Sales, Release No. 34-50103 (Final Rule)' (n 148) 48016.

${ }^{152}$ Enriques (n 50) 1147.

${ }^{153} \mathrm{Hu}$, 'Too Complex to Depict? Innovation, "Pure Information," and the SEC Disclosure Paradigm' (n 141) $1694-7$.

${ }^{154}$ SEC, 'Amendments to Regulation SHO, Release No. 34-60388 (Final Rule)' (27 July 2009) 12.
} 
participant failed to close out the position it became subject to the pre-borrowing penalty. $^{155}$

Although the SEC's move to eliminate FTDs was linked to a belief that FTDs had an effect on pricing efficiency and liquidity different from shares that deliver, ${ }^{156}$ as observed in section $\mathrm{C}$ above, economically this is not the case. Specifically, the impact of a short sale on market quality does not depend on whether it results in timely delivery at settlement. ${ }^{157}$ In addition, the US already has processes in place to tackle any FTDs. For instance, the National Securities Clearing Corporation (the 'NSCC') has a range of options for responding to FTDs including using shares in the selling member's stock account, utilising its stock borrow program to cover the shortfall, as well as the initiation of buy-in procedures by the long member. ${ }^{158}$ Further, while the position remains open, the seller will not receive the funds and the buyer can earn interest on the proceeds of the payment he retains until delivery. ${ }^{159}$ Given that NSCC processes already exist to tackle settlement disruption, the SEC's decision to remove the ability to fail can be queried, especially when 'progressive

\footnotetext{
${ }^{155}$ Regulation SHO, rule 204.

${ }^{156}$ See SEC, 'Emergency Order Pursuant to Section 12(K)(2) of the Securities Exchange Act of 1934 Taking Temporary Action to Respond to Market Developments, Release No. 34-58572' (17 September 2008); Veljko Fotak, Vikas Raman and Pradeep K. Yadav, 'Fails-to-Deliver, Short Selling, and Market Quality’ (2014) 114 Journal of Financial Economics 493, 495.

${ }^{157}$ Fotak, Raman and Yadav (n 156) 515.

${ }^{158}$ Culp and Heaton (n 47) 50. Note that the NSCC acts as the central counterparty for clearance and settlement of virtually all broker-to-broker equity (as well as corporate and municipal bond and unit investment) trading in the US. Through the continuous net settlement system, the NSCC settles trades from exchanges, markets, and other sources, and nets these transactions, DTCC, 'Continuous Net Settlement System and the NSCC' (2014) <http://www.dtcc.com/clearing-services/equities-clearingservices/cns.aspx (http://perma.cc/B5R8-CZKJ)> accessed 8 October 2014.

${ }^{159}$ Culp and Heaton (n 47) 50. Culp and Heaton also suggest that in this instance the buyer acts as an effective lender with a very solvent counterparty in the form of the NSCC. They also suggest that it provides the buyer with the ability to purchase a share that would not otherwise exist if the security was unavailable for borrowing from its current owner and that this creates desirable competition in the securities lending market.
} 
fines for settlement delay' could arguably be as effective without constituting such an extreme solution. ${ }^{160}$

During the crisis, the SEC also implemented a 'naked short selling anti-fraud rule', and subsequently adopted this permanently in October 2008. ${ }^{161}$ This rule was intended to further evidence the liability of short sellers who deceived specified persons (broadly, a broker-dealer; clearing agency participant, or a purchaser) about their intention or ability to deliver securities in time for settlement. ${ }^{162}$ Nevertheless the requirement neither substantively amplified nor extended the existing rules on naked short selling or market manipulation and the need for the SEC to introduce it at all can again be questioned. ${ }^{163}$

Essentially, the external political pressure that was placed on the SEC to tighten its regulatory restrictions on short selling played an important part with respect to the future direction of its policy. ${ }^{164}$ Indeed, as Sirri observes, with large scale regulatory reforms being negotiated on Capitol Hill, the SEC may not have wished to risk losing part of its authority over as transitory a matter as short selling, and pleasing Congressional critics 'may have been an essential part of the SEC policy tradeoff' ${ }^{165}$

(d) Concluding Remarks: EU and US Permanent Restrictions

\footnotetext{
${ }^{160}$ Fotak, Raman and Yadav (n 156) 496.

${ }^{161}$ Rule 10b-21 under the Securities and Exchange Act.

${ }^{162}$ SEC, 'Naked' Short Selling Anti-Fraud Rule, Release No. 34-58774 (Final Rule)' (14 October 2008).

${ }^{163}$ Grunewald, Wagner and Weber (n 45) 120.

${ }^{164}$ Sirri (n 20) 535.

${ }^{165}$ Ibid 535-6.
} 
Although the approach taken to permanent restrictions varies on both sides of the Atlantic, the result is functionally equivalent. The combination of the SEC's locate rule plus its tighter FTD rules are functionally equivalent to the EU's provisions: a de facto ban on naked short sales. Although this means regulators can eliminate any manipulative behaviour that does take place, it does so at the cost of market efficiency (and sophisticated market participants may also shift to unregulated equivalents). Indeed, rather than eliminating naked short sales, the US could instead consider tightening its settlement periods in line with the EU's shift to $\mathrm{T}+2$, in conjunction with the imposition of progressive penalties for FTDs.

The US has also gone even further than the EU in this area with the imposition of restrictions on all short sales before SEOs. However, there are no restrictions on the short selling of sovereign debt in the US as no such crisis materialised there triggering a regulatory response as it did in the EU. Nevertheless, as this section has demonstrated, on both sides of the Atlantic, a range of political pressures impacted on the post-crisis rule-making process and had a significant influence on the policymakers' approach to regulating short selling.

\section{E. Temporary Restrictions}

\section{The EU}

As observed in section D.1(b), the EU rules also provide for a range of temporary powers that NCAs can utilise in emergency situations, including temporary short 
selling bans and 'circuit breaker' powers. ${ }^{166}$ Further, unlike the permanent restrictions that apply specifically to shares (and only relate to direct short sales), the temporary restrictions extend to cover direct and synthetic short sales (including those created through derivatives). ${ }^{167}$

These additional powers are triggered when there are adverse events or developments constituting a serious threat to financial stability or to market confidence in the Member State or in one or more Member States, and the measure is necessary to address the threat and will not have a detrimental effect disproportionate to its benefits. ${ }^{168}$ The administrative rules set out a non-exhaustive list of factors to be taken into account in this regard. ${ }^{169}$ Broadly, this includes any act, result, fact or event that is or could reasonably be expected to lead to serious financial, monetary, or budgetary problems that may lead to financial instability concerning a Member State, a bank, or systemically important financial institution operating within the EU when this may threaten the orderly functioning and integrity of financial markets or the stability of the Union's financial system. ${ }^{170}$ Article $24(1)(\mathrm{b})$-(e) provide further examples including (in brief): default by a Member State; substantial selling pressure causing significant downward spirals in financial instruments related to systemically important financial institutions; relevant damage to physical structures of important financial issuers and others; and relevant disruption in any payment system or settlement process. Various notification requirements are also placed on the NCA. It

\footnotetext{
${ }^{166}$ The relevant NCA is the competent authority of the most relevant market in terms of liquidity of the financial instrument in question, Regulation 236/2012, art 2(1)(j)(v).

${ }^{167} \mathrm{Ibid}$, arts 20(2)-(3).

${ }^{168}$ Ibid art 20(1).

${ }^{169}$ Delegated Regulation 918/2012, art 24.

${ }^{170}$ Ibid art 24(1)(a).
} 
is required to publish notice of a decision to impose or renew a measure on its website, providing details of the measures imposed. ${ }^{171}$ The NCA must also notify the other NCAs, and ESMA, who will issue a public opinion on whether it considers the measure appropriate. ${ }^{172}$

\section{(a) Overview}

A number of emergency measures have been imposed in Greece, Italy, and Spain since the Regulation's introduction; two of which extended pre-existing national bans. ${ }^{173}$ Generally, ESMA has supported the imposition of these emergency measures, including the implementation and extension of a number of short selling bans by the Greek regulator (the Hellenic Republic Capital Market Commission ('HCMC')) when the Greek crisis reignited during 2015. ${ }^{174}$ ESMA's positive opinions have tended to be relatively brief, largely reiterating the Regulation's wording. ${ }^{175}$

In January 2016 however, ESMA issued a more detailed negative opinion with respect to the proposed extension of an emergency short selling ban by the Greek regulator regarding the shares of Attica Bank S.A. ${ }^{176}$ Specifically, ESMA considered

\footnotetext{
${ }^{171}$ Regulation 236/2012, art 25.

${ }^{172}$ Ibid, arts 25-27.

${ }^{173}$ See e.g. ESMA, Opinion on Spanish Emergency Measures (ESMA/2012/715); ESMA, Opinion on Greek Emergency Measures (ESMA/2013/542); ESMA, Opinion on Italian Emergency Measures (ESMA/2014/1355); ESMA, Opinion on Greek Emergency Measures (ESMA/2015/1066).

${ }^{174}$ In particular, Greece introduced a temporary short selling ban on 29 June 2015 on any financial instrument creating or increasing a net short position on any shares trading on the Athens stock markets. This prohibition was then subsequently extended by HCMC. On 30 September 2015, the HCMC also introduced a new emergency ban on the short selling of shares on five credit institutions admitted to trading on the Athens Exchange that was subsequently renewed on a number of occasions during the latter part of 2015, see e.g. ESMA, Opinion on Greek Emergency Measures (2015/1900).

${ }^{175}$ See e.g. ESMA, Opinion on Italian Emergency Measures (n 173).

${ }^{176}$ ESMA, Opinion on Greek Emergency Measures (ESMA/2016/28).
} 
that the threat to financial stability of Attica bank and the Greek financial market had 'considerably decreased', and took the view that renewing the measure was neither appropriate nor proportionate. ${ }^{177}$ Despite ESMA's opinion however, the Greek authorities disagreed, and imposed the ban for a further two-week period. ${ }^{178}$ HCMC stated that Attica Bank was the last of the Greek banks to be recapitalised and that it should be protected from short selling in the same manner as the other Greek credit institutions. ${ }^{179}$

This is the first time since the Regulation was implemented that ESMA has opposed a NCA's proposed emergency measure. ESMA provided quantitative analysis of Attica Bank's share price and concluded that its pricing history did not give the impression of a highly fragile situation. ${ }^{180}$ It also highlighted that Attica Bank's situation was different to the other Greek banks; in terms of quantitative significance with respect to financial stability, Attica Bank stood for only a very small segment of the Greek banking sector. ${ }^{181}$ ESMA also noted the presence of alternative tools under the Regulation (including the circuit breaker powers) that could be utilised as a more appropriate and proportionate short-term measure if there was a significant downward spiral in the price of the shares. ${ }^{182}$

It is likely that the wider political context and the fragility of Greek relations within the EU played a key part in driving HCMC's decision to extend its short selling ban.

\footnotetext{
177 Ibid 5-7.

${ }^{178}$ Hellenic Republic Capital Market Commission, Notice by the HCMC (2016) 1.

${ }^{179}$ Ibid 1-2.

${ }^{180}$ ESMA, Opinion on Greek Emergency Measures (n 176) 6.

${ }^{181}$ Ibid 7.

${ }^{182}$ Ibid 7.
} 
More broadly however, it is also likely that this will not be the only situation where a NCA and ESMA disagree as to the imposition of an emergency short selling measure. With this in mind, it still remains to be seen how much authority ESMA will seek to exert in practice going forward, especially in the event there is a difference of views, and where a coordinated response by NCAs across the EU is necessary. ${ }^{183}$

(b) Impact of the Emergency Bans

With respect to the economic impact of the emergency bans in practice, their effect has been largely mixed. For instance, in relation to the Spanish emergency ban, market participants observed reduced liquidity, and suggested that the bans distorted the fair value of securities by removing a large set of market participants. ${ }^{184} \mathrm{~A}$ high level of uncertainty also existed concerning the scope of the Spanish ban, including whether it encompassed index-linked instruments such as derivatives referenced to global or pan-European indices, which included one or more of the shares subject to the measure. ${ }^{185}$

As was explored in section $\mathrm{C}$, there is no conclusive evidence that taking short positions is harmful to the financial system or market confidence, and imposing restrictions may result in a loss of pricing efficiency and liquidity. Despite this, it is also recognised that viewpoints differ on this, and that this is also part of a more

\footnotetext{
${ }^{183}$ Moloney (n 2) 571-2.

${ }^{184}$ BME Spanish Exchanges, Comments on ESMA Call for Evidence (15 March 2013); ESMA, 'Technical Advice on the Evaluation of Regulation (EU) 236/2012 on Short Selling and Certain Aspects of Credit Default Swaps' (n 100) 44.

${ }^{185}$ See e.g. Allianz SE, Call for Evidence (15 March 2013). In particular there was dispute about whether short positions in foreign indices were banned solely because of Spanish shares in the relevant index. Part of this debate stemmed from the fact that such shorting had previously been permitted under the earlier national ban in certain circumstances (i.e. to hedge general market risk).
} 
complex story of the social benefits and harms that result from short selling. ${ }^{186}$ Nevertheless, it also remains clear that the benefits of imposing temporary bans have to be very carefully weighed against the longer-term and more subtle benefits that short selling provides and that this decision will ultimately involve a trade-off between financial stability and market efficiency. ${ }^{187}$ Further, given that restrictions do not necessarily achieve their desired aim, it is hard to see what is actually gained (aside from in a political sense) through their imposition. ${ }^{188}$ Finally, it could also be questioned whether introducing such measures are in fact 'necessary' and will not have a detrimental effect disproportional to its benefits. ${ }^{189}$

Reflecting on the more procedural aspects of the bans, market participants are currently required to check all NCA's websites and there is no requirement to publish information in a common language. Given the urgency inherent in imposing a temporary measure, it is vital that information is communicated to parties in a timely fashion, and this is not the case when reliance is placed on participants checking 28 NCA websites, plus the absence of a requirement for notification in a common language. ${ }^{190}$ In practice there has also been a lack of coordination between NCAs

\footnotetext{
${ }^{186}$ Merritt B Fox, Lawrence R Glosten and Paul C. Tetlock, 'Short Selling and the News: A Preliminary Report on Empirical Study Fear, Fraud, and the Future of Financial Regulation Symposium' (2009) 54 New York Law School Law Review 645, 683.

${ }^{187}$ As observed in section D.2(a) this will also depend on the agency's objective when making the decision. In the EU there is an analogy between the US Treasury and the Federal Reserve, and ESMA, whose objectives include reinforcing stable and well functioning markets. The situation becomes more complex at the national level however where a variety of institutional frameworks exist (e.g. a single regulator model; 'twin-peak' systems; etc.). Further, since the crisis, many existing frameworks have been dismantled (e.g. the UK's FSA) and (often divided) political views have been voiced as to what is the best institutional structure, see further e.g. Eilis Ferran, 'Understanding the New Institutional Framework of EU Financial Market Supervision' (University of Cambridge Faculty of Law Research Paper No 29/2011) 9-11.

${ }^{188}$ Enriques (n 50) 1149.

${ }^{189}$ Regulation 236/2012, art 20(1)(b); Eumedion, ESMA Call for Evidence (15 March 2013) 7-8.

${ }^{190}$ Societe Generale, Response to the ESMA Call for Evidence (March 2013) 2.
} 
when a ban has been imposed on an issuer's securities traded on several European venues. This has created uncertainty as to which instruments trading on what venues are within the scope of the restriction and has imposed unnecessary costs on commercial parties. ${ }^{191}$ Long and short trading of certain instruments outside the scope of the emergency measures has been affected during the period before participants reached absolute certainty in having their concerns addressed that the instrument may be within the measure's scope and this had immediate negative effects on price efficiency, liquidity and investment in such instruments. ${ }^{192}$

Although the European rules seek to avoid the go-it-alone strategies that dominated the financial crisis through allocating a relevant NCA in conjunction with notification requirements to other NCAs and ESMA, a lack of coordination remains. Although ESMA has an important oversight role, in the absence of utilising article 28 and intervening itself, it has no real authority to prevent NCAs from implementing incoherent approaches. ${ }^{193}$ Given the importance of a consistent approach in the event that short selling restrictions are to be imposed (if the rules are to have any impact), it may be seem sensible, although controversial, to also transfer these powers to ESMA. On a more practical note, to reduce communication issues in practice, it would be useful to introduce a single platform or website to transmit information and require all communications to be in a common language or translated into all necessary languages.

\footnotetext{
${ }^{191}$ AIMA, AIMA/MFA Response to the Call for Evidence by ESMA (15 March 2013) 12.

${ }^{192}$ Ibid 12.

${ }^{193}$ Rodolphe Baptiste Elineau, 'Regulating Short Selling in Europe after the Crisis' (2012) 8 International Law \& Management Review 61, 83.
} 
(c) Circuit Breakers

The Regulation also provides for a circuit breaker mechanism: the power to temporarily restrict short selling of financial instruments on trading venues in the case of a significant fall in price during a single trading day in relation to the closing price on the previous day. ${ }^{194}$ The NCA of the home Member State for that venue will consider whether it is appropriate to prohibit or restrict short selling of that instrument or otherwise limit transactions to prevent a disorderly decline in the price. ${ }^{195} \mathrm{In}$ contrast to the temporary prohibitions, this mechanism is not subject to the adverse event that constitutes a threat to financial stability' condition. Rather, the Regulation provides that the intra-day fall in value that triggers consideration as to whether to exercise the powers shall be 10 per cent or more for liquid shares. ${ }^{196}$ The initial prohibition shall apply for a period not exceeding the end of the trading day following the trading day on which the price fall occurs. This can be extended for a further period not exceeding two further trading days if there is a further significant fall of at least half the amount specified (for example, for liquid shares this will be a further five per cent). ${ }^{197}$

The NCA must again publish notice of any decision to impose or renew such measures on its website and notify the other NCAs and ESMA. ESMA is less involved with this power due to the urgency inherent in the circuit breaker measure

\footnotetext{
${ }^{194}$ Regulation 236/2012, art 23.

${ }^{195}$ Ibid art 23(1).

${ }^{196}$ Ibid art 23(5). See Delegated Regulation 918/2012, art 23 sets out the relevant thresholds for illiquid shares and other types of financial instrument.

${ }^{197}$ Regulation 236/2012, art 23(2) and (5).
} 
but ESMA shall immediately inform the NCAs of the home Member States of venues that trade the same instrument. ${ }^{198}$

\section{(d) Circuit Breakers in Practice}

A number of temporary prohibitions have been imposed since the Regulation's implementation. For instance in January and April 2013, seven temporary bans were imposed by the Italian regulator, CONSOB on Italian shares trading on the Milan stock exchange. Equally, in July 2013, Portugal imposed a one-day short selling ban on the shares of four companies. Short selling in one of these Portuguese firms (a bank) was also temporarily restricted again in July $2014 .{ }^{199}$ In some instances, their imposition has been followed by other NCAs who considered it useful to also impose a ban on platforms where the shares were traded.

Due to the various notifications required, the restrictions have been imposed with a non-trivial delay. For instance, the regulator announced the Portuguese ban several hours before it would take effect. Likewise, in relation to the Italian restrictions, there was a non-trivial delay between the threshold being crossed and CONSOB announcing the ban. Such gaps limit a measure's effectiveness as they can enable shrewd traders who act quickly to trade ahead of a ban's imposition. Similarly, by the time the Italian restrictions were announced, prices had already stabilised or

\footnotetext{
${ }^{198}$ Ibid, art 23(4). Note that there is a limited window for other NCAs to disagree and ESMA may act as mediator.

${ }^{199}$ Indeed, the bank was subsequently restructured and split into a 'good' and 'bad' bank under a bailout plan and the shares were delisted, see e.g. Chad Bray, 'Short-Selling of Banco Espírito Santo Briefly Banned' The New York Times (1 July 2014).
} 
rebounded and transaction volumes were starting to normalise. ${ }^{200}$ A further problem has stemmed from the overlap of automatic trading interruption mechanisms on trading venues ('automatic circuit breakers'), which also begs the question whether additional circuit breakers were necessary in the first place. Further, due to uncertainty relating to decisions at other venues to introduce restrictions or take no action, market participants may have stopped all short shares on trading venues. Alternatively if they chose to proceed with short sales at other venues, they retained the possibility to arbitrage with prices on the home venue. ${ }^{201}$

Considering the Italian bans, there have also been implementation inconsistencies between NCAs. For instance a CONSOB ban with respect to the Italian firm Saipem was implemented for one and a half days whereas the UK's FSA imposed it for only one day. Equally, the Italian ban allowed for a market-making exemption whereas the UK measure did not. The individual bans were also released to the market and on each NCA's website at different times during the trading day. There have also been criticisms concerning procedure including the short time frame for decision-making; the lack of information published on the NCA's website; and the method for publication and communication. ${ }^{202}$ Likewise, the thresholds are too low: 10 per cent may be far too small a drop to contemplate a ban on a liquid share in most circumstances. $^{203}$

\footnotetext{
${ }^{200}$ ESMA, 'Technical Advice on the Evaluation of Regulation (EU) 236/2012 on Short Selling and Certain Aspects of Credit Default Swaps' (n 100) 77.

201 Ibid 82.

202 Ibid 47.

${ }^{203}$ For instance, when BP's share price plummeted by 50 per cent following the Gulf of Mexico oil spill in 2010 this did not mean there was a case for banning short selling of its shares, APCIMS, Response by the Association of Private Client Investment Managers and Stockbrokers (2010). It also seems unnecessary to restrict trading in SME markets, as it is hard to conceive of circumstances when a significant decline in price in such securities would likely threaten financial stability.
} 
Similar criticisms have been levied at the circuit breakers as with the longer bans including the ineffectiveness of measures imposed by only one regulator. The related uncertainty as to which instruments are included has led to market confusion and imposed extra investigative costs on parties. Given that trading venues typically have automatic circuit breakers that could interrupt trading if necessary, the new requirements seem superfluous and create extra implementation issues. Indeed, with some of these issues in mind, ESMA proposed reworking the provisions, including in order to make the process more straightforward and to allow a NCA to exercise its judgment as to if and when a temporary measure was necessary. ${ }^{204}$ Nevertheless the Commission opted against making any changes and proposed a new evaluation by the end of 2016 when more extensive empirical data and evidence would be available. ${ }^{205}$ More generally, it is suggested that the regulator should not be in the habit of simply stopping price declines; the market should be able to price in disaster. In most cases it is not short selling that gives rise to a price fall but other factors such as poor company results and economic fundamentals.

\section{(e) ESMA's Powers}

Aside from its coordination role, ESMA has a number of other powers (including the ability to conduct inquiries and coordinate on-site inspections with cross-border effects). Most notably however, it is also granted direct intervention powers under article 28 of the Regulation, and the political decision to confer these powers on

\footnotetext{
${ }^{204}$ ESMA, 'Technical Advice on the Evaluation of Regulation (EU) 236/2012 on Short Selling and Certain Aspects of Credit Default Swaps' (n 100) 51.

${ }^{205}$ Commission, 'Report on the Evaluation of the Regulation on Short Selling and Certain Aspects of Credit Default Swaps' (December 2013) 7.
} 
ESMA was taken before the Regulation's adoption during the broader negotiations for the founding regulations creating ESMA and the other European Supervisory Authorities. $^{206}$

Article 28 enables ESMA to prohibit or impose conditions on the entry into short sales or equivalent transactions in exceptional circumstances (sovereign debt is excluded from this power). ${ }^{207}$ ESMA can use its direct powers to address a threat to the orderly functioning and integrity of financial markets or the stability of the whole or part of the EU's financial system, there are cross-border implications, and no NCA has taken measures to address the threat, or one or more authorities have taken measures that do not adequately address the threat. ${ }^{208}$ The administrative measures elaborate on what constitutes exceptional circumstances and the provisions are similar to the conditions required for NCA emergency action. ${ }^{209}$ When taking such measures, ESMA shall also take account of the extent the measure significantly addresses the threat or improves the NCA's ability to monitor the threat, does not create a risk of regulatory arbitrage, and does not have a detrimental effect on the efficiency of financial markets. ${ }^{210} \mathrm{~A}$ range of procedural requirements are also placed on ESMA, including prior consultation with the European Systemic Risk Board (a post-crisis Union level body with a mandate to oversee risk in the overall financial system) and prior notifications to the NCAs concerned by the measure. ${ }^{211}$ ESMA is required to

\footnotetext{
${ }^{206}$ Moloney (n 2) 567.

207 Regulation 236/2012, art 28(1). Note that ESMA is also empowered to impose reporting requirements on persons under article 28.

${ }^{208}$ Ibid art 28.

${ }^{209}$ Delegated Regulation 918/2012, art 24(3). Although, article 24(3) is related to threats to Member States' or their financial systems rather than banks or other financial institutions.

${ }^{210}$ Regulation 236/2012, art 28(3).

${ }^{211}$ Ibid arts 28(4)-(5).
} 
publish notice of the decision on its website and any measure will prevail over previous measures taken by a NCA. ${ }^{212}$

The conferral of the article 28 powers on ESMA considerably expands its authority beyond that granted to its predecessor, CESR, and marks a significant step forward with respect to EU intervention in markets. ESMA is placed at the centre of important and delicate decisions with respect to short selling, and it could, potentially, be in a position to exert much influence going forward. ${ }^{213}$ With this in mind, it is perhaps unsurprising that ESMA's article 28 powers were the subject of a legal challenge by the UK in 2012 at the European Court of Justice (the 'Court'). The UK challenged ESMA's powers on a number of grounds, including that ESMA had been granted a large measure of discretion at odds with European principles on the delegation of powers; and submitting that article 114 of the Treaty on the Functioning of the EU ('TFEU') was the incorrect legal basis for the adoption of article $28 .{ }^{214}$ Nevertheless, although the Advocate General supported the UK with respect to its article 114 TFEU submission, in January 2014, the Court rejected the UK's challenge. It affirmed ESMA's powers of intervention, as well as the legislative choice of legal basis for the adoption of article $28 .^{215}$

\footnotetext{
${ }^{212}$ Ibid art 28(11).

${ }^{213}$ Moloney, 'Reform or Revolution? The Financial Crisis, EU Financial Markets Law, and the European Securities and Markets Authority' (n 53) 532. Note that this shift to centralise powers in ESMA is also evident in other post-crisis initiatives, including AIFMD and EMIR.

${ }^{214}$ For a detailed discussion of this case, see e.g. Carl Fredrik Bergström, 'Shaping the New System for Delegation of Powers to EU Agencies: United Kingdom v. European Parliament and Council (Short Selling)' (2015) 52 CML Rev 219; Noia and Gargantini (n 4); Elizabeth Howell, 'The European Court of Justice: Selling Us Short?' (2014) 11 ECFR 454.

${ }^{215}$ Case C-270/12 United Kingdom $v$ Council of the European Union and European Parliament ECLI:EU:C:2014:18, paras 112, 114-115.
} 
Despite the renewed turmoil in the financial markets recently, ESMA has not yet resorted to its article 28 powers in practice and so it still remains to be seen how it will use its new direct powers. Nevertheless, as Moloney suggests, notwithstanding the Court's confirmation of ESMA's powers of intervention, given the various political sensitivities surrounding article 28, it may be that ESMA chooses to be relatively circumspect before utilising its direct powers. ${ }^{216}$

2. The US: Temporary Restrictions

(a) Original Price Test

Across the Atlantic, historically, the SEC restricted short selling using what was commonly referred to as the 'uptick rule'. This was implemented in 1938 and essentially required that before a security could be sold short the price had to rise, indicating there were active buyers in the market. ${ }^{217}$ Despite many changes in the securities market, including the conversion to decimal pricing increments, increased trading volumes and the advent of electronic trading, the main provisions remained virtually unchanged until its repeal in $2007 .{ }^{218}$ Empirical studies (including a multiyear pilot conducted by the SEC) also demonstrated that the rule hindered short selling's efficiency aspects, did not halt price declines, and could have an adverse effect on the execution quality of short sale orders, even when they traded in

\footnotetext{
${ }^{216}$ Moloney (n 2) 569.

${ }^{217}$ Securities Exchange Act 1934, rule 10a-1. See also Helena Stigmark, 'Should Short Selling Be Regulated as a Consequence of Wall Street's Failures? Exploring the New Alternative Uptick Rule' (2010) 30 The Michigan Business Law Journal 32, 33.

${ }^{218}$ SEC, 'Regulation SHO and Rule 10a-1, Release No. 34,55970 (Final Rule)' (28 June 2007) 4-5. Such changes meant that the rule was less of an impediment to short selling.
} 
advancing markets. ${ }^{219}$ After a process involving the pilot, other empirical studies, plus opportunities for public comment, the SEC voted to remove the rule.

At the time this news caused little public notice, however once the crisis took hold the SEC faced increasing criticism for its decision. The pressure in fact mounted to the point that the rule's repeal was described as a breach of public trust and grounds for the SEC Chairman's dismissal. ${ }^{220}$ Although the SEC explicitly stated it was not aware of economic evidence that the elimination of the price test contributed to increased volatility in the US markets, the SEC started to meet with many demands to reinstate a price test, and in February 2010 it introduced 'alternative uptick rule': a variant on the original test. ${ }^{221}$

(b) The Alternative Uptick Rule

The new rule consists of a circuit breaker combined with an alternative uptick rule. Trading centres are to have policies in place to prevent the execution or display or a short sale order of a security at a price less than or equal to the national best bid if the price of the security decreases by 10 per cent or more from the closing price as determined by the listing market for the security as of the end of regular trading hours on the previous day. ${ }^{222}$ The requirements are then imposed for the remainder of the

\footnotetext{
${ }^{219}$ Office of Economic Analysis, 'Economic Analysis of the Short Sale Price Restrictions under the Regulation SHO Pilot' (6 February 2007); Lynn Bai, 'The Uptick Rule of Short Sale Regulation: Can It Alleviate Downward Price Pressure from Negative Earnings Shocks' (2008) 5 Rutgers Bus LJ 1; Gordon J. Alexander and Mark A. Peterson, 'Short Selling on the New York Stock Exchange and the Effects of the Uptick Rule' (1999) 8 Journal of Financial Intermediation 90.

${ }^{220}$ Sirri (n 20) 536.

${ }^{221}$ SEC, 'Amendments to Regulation SHO, Release No. $34-59748$ (Proposed Rule)' (10 April 2009) 17.

${ }^{222}$ Regulation SHO, rule 201.
} 
day and the following day and if the price continues to fall so the circuit breaker is retriggered, the restriction period will restart. It applies to all national market system ('NMS') stocks (i.e. any NMS security other than options) listed on a national securities exchange. ${ }^{223}$ Broadly, this means it applies to all equity securities listed on a national securities exchange whether traded on exchange or OTC. The restrictions apply only at such times as the national best bid for the security is calculated and disseminated on a current and continuing basis by a plan processor pursuant to a NMS plan. ${ }^{224}$ It does not extend to derivative securities and there are only very limited exemptions from the rule (for instance the SEC decided not to provide an exemption for bona fide market-making activity).

The SEC stated that its aims were to prevent short selling from driving down the price of a security that had experienced a 10 per cent decline and to allow long sellers to stand at the front of the line and sell first in a declining market. ${ }^{225}$ The SEC also particularly focused on the rule's ability to restore 'investor confidence'. Specifically, the SEC Chairman (Mary Schapiro) stated it was a rule designed to preserve investor confidence and promote market efficiency. ${ }^{226}$

The SEC's arguments in relation to introducing the new rule are un-compelling. There is no empirical evidence that the uptick rule's repeal contributed to steep declines in stocks and increased volatility, and there is no evidence questioning the efficacy of

\footnotetext{
${ }^{223}$ SEC, 'Amendments to Regulation SHO, Release No. 34-61595 (Final Rule)' (February 26, 2010) $45-46$.

${ }^{224}$ Ibid 89. As the times the NMS plans disseminate information are different this means the price restrictions may apply at different hours enabling some short sales to fall through the net.

${ }^{225}$ Ibid 1-2.

${ }^{226}$ Mary Schapiro, 'Speech by SEC Chairman: Statement at SEC Open Meeting — Short Sale Restrictions' (24 February 2010) 1.
} 
the pilot studies supporting its repeal. ${ }^{227}$ The vague concept of investor confidence also affords the SEC too much discretion to regulate and more is necessary to justify restricting short selling, especially in the light of evidence that advised against imposing such a test. ${ }^{228}$ The SEC's adopting release also repeatedly relies on the circuit breaker feature to discount the risk that the rule would adversely affect market quality. This does not mean a price test is then merited. ${ }^{229}$ Indeed, on a related point concerning the circuit breaker, and in line with the observations in relation to the EU, the 10 per cent threshold seems disproportionate: it is doubtful this reflects a situation of severe deterioration and the market will also factor in its existence. ${ }^{230}$

Further, restricting short selling to allow long sellers to sell first may mean investors are less likely to buy shares when constraints increase the cost of hedging. ${ }^{231}$ Likewise, short selling constraints can lead to inflated prices as short sellers' views will not be fully integrated into the market and this could lead to investors being less willing to go long or to insist on paying less when purchasing shares. ${ }^{232}$ On a related point, the rule's adoption suggests that short selling is viewed as being less legitimate than long selling. This is a common popular perception but as this article has illustrated, short sellers provide a valuable role in markets, including preventing prices from being artificially inflated. Further, during the financial crisis, it was long

\footnotetext{
${ }^{227}$ SEC, 'Amendments to Regulation SHO, Release No. 34-61595 (Final Rule)' (n 223) 34, 39; Kathleen Casey, 'Speech by SEC Commissioner: Statement at Open Meeting Short--Sale Restrictions' (24 February 2010) 1-2.

${ }^{228}$ This included studies by the SEC's own Office of Economic Analysis, see Troy Paredes, 'Speech by SEC Commissioner: Statement at Open Meeting and Dissent Regarding the Adoption of Amendments to Regulation SHO' (24 February 2010) 6.

${ }^{229}$ Ibid 8.

${ }^{230}$ Grunewald, Wagner and Weber (n 45) 124.

${ }^{231}$ Paredes (n 228) 7.

${ }^{232}$ Ibid 7.
} 
rather than short sellers that particularly contributed to the price pressure on financial stocks and the extreme negative returns. ${ }^{233}$

Ultimately the strongest case for adopting the rule is that it 'may mollify those who have been clamouring for reinstatement of the uptick rule and show that we have responded to their concerns'. ${ }^{234}$ This is not the standard by which to craft rules and the SEC should resist the urge to act merely to say it had acted. Nevertheless, when reflecting on the EU in comparison however, at least it chose not to follow the SEC in relation to this branch of its regulatory policy. ${ }^{235}$

(c) EU and US Temporary Rules: Concluding Remarks

From examining the European and US rules, it becomes clear that the Regulation's temporary constraints can potentially have a wider ambit than those in place in the US; the rules can extend to encompass any financial instrument that creates a short position. In contrast, the US's alternative uptick rule does not have such a broad application, applying only to equity securities and not extending to synthetic

\footnotetext{
${ }^{233}$ Office of Economic Analysis, 'Analysis of Short Selling Activity During the First Weeks of September 2008' (2008) 2-3. See also an empirical study by Jain et al. that was unable to document any clear benefits deriving from the alternative uptick rule, see Chinmay Jain, Pankaj K. Jain and Thomas H. McInish, 'Short Selling: The Impact of SEC Rule 201 of 2010' (2011) University of Memphis Working Paper <http://papers.ssrn.com/sol3/papers.cfm?abstract_id=1718137> accessed 27 February 2014; Chinmay Jain, Pankaj K. Jain and Thomas H. McInish, ‘Everything Old Is New Again' (2011) 34 Regulation 30.

${ }^{234}$ Casey (n 227) 2-3.

${ }^{235}$ See e.g. Impact Assessment (n 26) 41, where the Commission acknowledges the many disadvantages with introducing a type of price test.
} 
equivalents. ${ }^{236}$ As this section has illustrated however, the US has gone further than the EU in this area of its policy through re-imposing a type of price test.

Divergences in regulatory response between the jurisdictions may create extra costs and difficulties for market participants. ${ }^{237}$ Further, the absence of a co-ordinated, global response can enable sophisticated traders to work around the rules relatively easily through engaging in regulatory arbitrage. ${ }^{238}$ Although this could be perceived to be a welcome outcome given the drawbacks associated with short selling restrictions, it is suggested that this is not the right solution. It undermines the attempts at regulation and new problems may materialise, not least due to the uncertainties created through the presence of different regimes. ${ }^{239}$

Indeed, such issues have already been observed within the EU's regime in practice; the lack of 'joined up thinking' between the NCAs when temporary restrictions have been imposed has caused uncertainty and imposed additional costs on commercial parties. Further, although ESMA's enhanced role within the EU's short selling regime is a significant development (and its recent negative opinion on the proposed extension of Greek temporary ban is notable in this regard), it still remains to be seen how assertive ESMA will be in utilising its authority in a future crisis, especially when a coordinated NCA response is required. In the US, the SEC is the sole short selling regulator and should, in theory, avoid the operational difficulties observable

\footnotetext{
${ }^{236}$ Although beyond the scope of the article, it is acknowledged that this could be in part due to jurisdictional boundaries that exist between the SEC and the Commodity Futures Trading Commission (the 'CFTC').

${ }^{237}$ Payne (n 9) 428.

${ }^{238}$ It is acknowledged however that the likelihood of achieving global short selling rules may be unrealistic, especially in the post-crisis era where arguments against seeking uniformity with respect to international rule-making have gained much impetus.

${ }^{239}$ Moloney (n 2) 20.
} 
within the EU. Nevertheless, the SEC has had to respond to other political and popular pressures post-crisis, and it has had to switch its focus from ensuring market efficiency in order to react to concerns related to maintaining financial stability. ${ }^{240}$

\section{F. Conclusion}

To revisit first principles, it is important to remember that the economic literature almost overwhelmingly endorses the importance of conventional and naked short selling for efficient markets; and that restricting short selling prevents markets being more efficient. Indeed, despite the fixation with naked short selling, and the fundamental distinction drawn between naked and covered short selling in the EU and the US, it is not a special case and there are not stronger justifications for its regulation. Despite this, and although not terming it as such, both the US and the EU have now implemented a de facto ban on the naked short selling of shares. Further, although functional similarities are now apparent between the two regimes with respect to naked short selling, a number of other regulatory differences remain. Indeed, in this regard, the introduction of the EU short selling rules that include restrictions with respect to the sovereign debt markets, do little to 'close the gap'. ${ }^{241}$

Next, in both jurisdictions, the politicisation of the legislative process had a major impact on the shape of the final rules. In the EU, this is most clearly reflected in the

\footnotetext{
${ }^{240}$ Indeed as Hu observes, the SEC's independence may be even more problematic going forward due to the creation of the Financial Stability Oversight Council ('FSOC') established under the Dodd-Frank legislation. The FSOC's members include the Treasury Secretary, the Federal Reserve Board Chairman, and the SEC Chairman, and one of its purposes is to respond to emerging threats to financial stability. Hence, as Hu notes, going forward, the SEC will be required to explicitly consider financial stability issues, see further Hu, 'Efficient Markets and the Law: A Predictable Past and an Uncertain Future' (n 142) 193.

${ }^{241}$ Payne (n 9) 440.
} 
rules on sovereign debt, further articulated through the absence of equivalent rules on corporate bonds. In the US, it can be observed especially through the reimplementation of a type of tick test. Indeed, when reflecting on the short selling constraints that are in place, it is the US that now has the more onerous set of restrictions, and this outcome can perhaps be best explained by the SEC being directly 'under the cosh' of Congress, post-crisis.

Returning to the big picture, as this article observed at its outset, short selling is a controversial topic, and the issue of its regulation tends to generate more heat than light. ${ }^{242}$ Views have differed on it since the $17^{\text {th }}$ Century, ${ }^{243}$ and the debate continues today when many continue to feel that the practice is morally wrong. Short sellers have a tendency to be blamed during major crises, and the backlash that follows such an event then creates the opportunity to push through reforms that have little true connection with the crisis. ${ }^{244}$ Post-crisis developments in both the EU and the US appear to support this suggestion, ${ }^{245}$ and perhaps, with the short selling restrictions now in place on both sides of the Atlantic, it is the politicians, rather than the speculators, who have sold us short.

\footnotetext{
${ }^{242}$ Fox, Glosten and Tetlock (n 186) 646.

${ }^{243}$ See e.g. Arturo Bris, William N. Goetzmann and Ning Zhu, 'Efficiency and the Bear: Short Sales and Markets around the World' (2007) 62 J Fin 1029 and the discussion of profitable shorting of shares in the Dutch East India Company that angered shareholders and led to the first short sale prohibitions being enacted in 1610 .

${ }^{244}$ See e.g. Ferran (n 57).

${ }^{245}$ They also illustrate that in general, a more interventionist approach to short selling regulation emerged in the light of the crises. Indeed in the EU, this can be contrasted with the absence, historically, of any short selling regulation in many EU jurisdictions, as well as the regulatory pause that characterised the pre-crisis years. Similarly, in the US, the SEC, who had been gradually paring back its onerous short selling rules in the pre-crisis years, then faced demands to revert to a more restrictive policy.
} 